Article

\title{
Modulation of Adenosine Receptors and Antioxidative Effect of Beer Extracts in in Vitro Models
}

\author{
Patricia Alonso-Andrés, Mairena Martín and José Luis Albasanz * (D) \\ Department of Inorganic and Organic Chemistry and Biochemistry, Faculty of Chemical and Technological \\ Sciences, School of Medicine of Ciudad Real, Regional Center of Biomedical Research (CRIB), University of \\ Castilla-La Mancha (UCLM), 13071 Ciudad Real, Spain; patrialan22@gmail.com (P.A.-A.); \\ mairena.martin@uclm.es (M.M.) \\ * Correspondence: jose.albasanz@uclm.es; Tel.: +34-926-295-300
}

Received: 10 April 2019; Accepted: 31 May 2019; Published: 3 June 2019

\begin{abstract}
The fight against neurodegenerative diseases is promoting the searching of nutrients, preferably of wide consumption, with proven effects on health. Beer is widely consumed and has potential benefits on health. In this work, three different extracts from dark beer (DB), non-alcoholic beer (NAB), and lager beer (LB) were assayed at $30 \mathrm{~min}$ and $24 \mathrm{~h}$ in rat $\mathrm{C} 6$ glioma and human SH-SY5Y neuroblastoma cells in order to study their possible protective effects. Cell viability and adenosine $A_{1}, A_{2 A}, A_{2 B}$, and $A_{3}$ receptor gene expression and protein levels were measured in control cells and in cells challenged with hydrogen peroxide as an oxidant stressor. Among the three extracts analyzed, DB showed a greater protective effect against $\mathrm{H}_{2} \mathrm{O}_{2}$-induced oxidative stress and cell death. Moreover, a higher $\mathrm{A}_{1}$ receptor level was also induced by this extract. Interestingly, $\mathrm{A}_{1}$ receptor level was also increased by NAB and LB extracts, but to a lower extent, and the protective effect of these extracts against $\mathrm{H}_{2} \mathrm{O}_{2}$ was lower. This possible correlation between protection and $\mathrm{A}_{1}$ receptor level was observed at $24 \mathrm{~h}$ in both $\mathrm{C} 6$ and SH-SY5Y cells. In summary, different beer extracts modulate, to a different degree, adenosine receptors expression and protect both glioma and neuroblastoma cells from oxidative stress.
\end{abstract}

Keywords: adenosine receptors; oxidative stress; beer

\section{Introduction}

The development of neurodegenerative diseases that include dementia, as in Alzheimer's disease (AD), has been partially associated with nutritional factors [1,2]. There are several compounds taken from the diet with protective effect against dementia, such as antioxidants (some vitamins) or flavonoids [3], that would protect other beneficial compounds against oxidation (e.g., polyunsaturated fatty acids, PUFAs) [4]. Therefore, the beneficial properties of low alcoholic graduation like that of beer could be associated with antioxidant strength [5], due to the presence of natural compounds such as xanthohumol [6] and resveratrol [7].

Beer is one of the most consumed drinks, after water and tea [8]. This beverage has as ingredients water, malt, non-malted cereals, hops, and yeast (which is responsible for the fermentation process) [9]. Moreover, there are more than 800 organic compounds present in the raw materials or produced by fermentation that act as flavorings [10]. Therefore, it is very difficult to generalize about beer composition, because each beer contains a wide range of compounds, depending on the raw materials used for its production and the brewing process [11].

In addition, beer contains several polyphenols, including flavonoids and phenolic acids, that are responsible for its organoleptic properties, such as flavor, and appearance 
Due to its composition, including polyphenols (e.g., flavonoids and phenolic acids), several beneficial effects on health have been associated to beer, such as a diuretic effect, a high nutritional contribution (vitamins, fibers, and antioxidants), and hunger stimulation in aging [5,11-13].

Neurological effects are observed after flavonoids (e.g., sophorine) intake, associated with the prevention of neurological diseases such as Parkinson's disease (PD) [14,15]. Beer is able to contribute to the increase of silicon quantity by limiting aluminum availability, considered a neurotoxin in $A D$, and by normalizing antioxidant enzymes gene expression and tumoral necrosis factor levels [16]. Other studies propose a moderate intake of beer in order to decrease beta-amyloid peptide aggregation [17], activate microglia, and prevent inflammation [18]. Oxidative stress is a factor involved in aging processes [19]. In neurodegenerative diseases such as $\mathrm{AD}$, oxidative stress is enhanced during the development of the disease [20]. Several studies have tested compounds for their ability to improve cognitive capacities in AD models, reducing oxidative stress and other associated processes. For example, ellagic acid is able to reduce oxidative stress in SH-SY5Y cells and in rats with streptozotocin-induced Sporadic Alzheimer Disease [21]. In addition, hydroxyurea attenuates oxidative stress in hippocampal neurons in rat, improving spatial memory in mice model of AD [22].

Several molecular targets have been described for polyphenols, specifically resveratrol, as estrogen receptor $\alpha$, cyclooxygenase $1, \mathrm{NF}-\mathrm{KB}$, and adenosine receptors [23,24]. Adenosine is a ubiquitous and homeostatic molecule considered a neuromodulator that exerts its effects through four specific $G$ protein-coupled receptors: $A_{1}, A_{2 A}, A_{2 B}$, and $A_{3}$ [25]. It has been suggested that adenosine has a role in neurodegenerative diseases, including $\mathrm{AD}$ [26]. In fact, $\mathrm{A}_{1}$ and $\mathrm{A}_{2 \mathrm{~A}}$ receptors are increased in the frontal cortex of AD patients [27], while several studies claim that caffeine intake, a potent antagonist of adenosine $A_{2 A}$ receptors, improves cognitive capacities in $\mathrm{AD}$ patients [28,29]. Adenosine regulates neuroplasticity, cognitive and motor function, and emotion behaviors and it is related to many cerebral dysfunctions in human diseases [30,31]. Additionally, adenosine receptors function and level have been involved in neuroprotective and antitumoral mechanisms in C6 [32-37] and SH-SY5Y cells [32,38-41].

It has been described that some polyphenols acting through adenosine receptors have an important implication in many several physiological processes. For example, the topic application of trans-resveratrol in rats is able to reduce ocular hypertension, in which adenosine $\mathrm{A}_{1}$ receptors are involved [42]. We have recently described the relation between adenosine receptors and polyphenols (resveratrol) in SAMP8 mice, suggesting the role of resveratrol through adenosine receptors and a possible participation in neuroprotective effects in neurodegenerative diseases [43]. Moreover, we have recently demonstrated that resveratrol, present in beer and wine, is able to modulate adenosine receptors by acting as a non-selective agonist of adenosine receptors in C6 glioma cells [24].

Therefore, the aim of the present work was to study the potential antioxidant protective effect and the possible modulation of adenosine receptors by three different commercial beer extracts (dark, non-alcoholic, and lager beers). To this end, two cellular models were used, rat C6 glioma and human SH-SY5Y neuroblastoma cells, which endogenously express adenosine receptors.

\section{Materials and Methods}

\subsection{Materials}

$\left[{ }^{3} \mathrm{H}\right]-D P C P X \quad$ (8-Cyclopentyl-1,3-dipropylxanthine) $(118 \mathrm{Ci} / \mathrm{mmol})$ and $\left[{ }^{3} \mathrm{H}\right]-\mathrm{ZM} 241385$ ([2- $\left.{ }^{3} \mathrm{H}\right]$ (4-(2-[7-amino-2-(2-furyl) [1,2,4] triazolo [2,3- $\left.\alpha\right]$ [1,3,5] triazin-5-ylamino] ethyl) phenol) $27.4 \mathrm{Ci} / \mathrm{mmol}$ ) were purchased from Amersham Biosciences (Buckinghamshire, UK). Theophylline and hydrogen peroxide were acquired from Sigma Aldrich (Madrid, Spain). CPA ( $\mathrm{N}^{6}$-Cyclopentyladenosine) was obtained from Tocris (Madrid, Spain). The Liquid scintillation cocktail was supplied by Perkin Elmer (Boston, MA, USA). Additional reagents were of analytical grade. 


\subsection{Cell Culture}

Rat C6 glioma and human SH-SY5Y neuroblastoma cells were obtained from the American Type Culture Collection (ATCC). C6 cells were grown as described elsewhere [44]. For C6, Dulbecco's modified Eagle's medium was supplemented with $10 \%$ fetal bovine decomplemented serum (PAA, Parching, Austria), $2 \mathrm{mM}$ L-glutamine, 1\% non-essential amino acids, $1 \%$ antibiotic-antimycotic, and $50 \mu \mathrm{g} / \mathrm{mL}$ gentamicin (Gibco, Waltham, MA, USA). SH-SY5Y were grown in DMEM supplemented with $10 \%$ fetal bovine serum and $1 \%$ antibiotic-antimycotic [39]. Both cell types were grown in a humidified atmosphere of $95 \%$ air and $5 \% \mathrm{CO}_{2}$ at $37{ }^{\circ} \mathrm{C}$. C6 and SH-SY5Y cells were subcultured in $10 \mathrm{~mL}$ Petri dish (Nunc, Roskilde, Denmark). At confluence, $\mathrm{C} 6$ were detached by mechanical action, whereas SH-SY5Y were detached by trypsin (Tryple Express, Gibco, USA). In both cases, the cells were resuspended in complete growth medium and plated in 24- or 96-well dished (Nunc, Roskilde, Denmark) as necessary.

\subsection{Cell Viability Assay}

Cell viability was determined using an in vitro colorimetric assay kit based on the reduction of tetrazolium salt (XTT) converted to formazan in the presence of an electron-coupling agent, purchased from Roche (Cell Proliferation Kit II, XTT). C6 and SH-SY5Y cells were seeded (10 ${ }^{4}$ cells per well) in 96-well dishes and exposed to beer extracts and/or an oxidant agent $\left(50 \mu \mathrm{M} \mathrm{H}_{2} \mathrm{O}_{2}\right)$ for $30 \mathrm{~min}$ or $24 \mathrm{~h}$. The cells were incubated with the XTT solution for $30 \mathrm{~min}$ at $37^{\circ} \mathrm{C}$. The cleavage of XTT to form an orange formazan dye by viable cells was monitored by reading the absorbance at 475 and $690 \mathrm{~nm}$, according to the manufacturer's protocol (Cell Proliferation Kit II, XTT, Roche, Mannheim, Germany).

\subsection{Beer Extracts Preparation}

Three extracts were obtained from three different commercial brands of dark, non-alcoholic, and lager beers. A volume of $500 \mu \mathrm{L}$ of beer was concentrated by SpeedVac, totally losing its alcohol content, and resuspended in $150 \mu \mathrm{L}$ of cell culture medium before treatments (50 $\mu \mathrm{L}, 30 \mathrm{~min}$, or $24 \mathrm{~h}$ ).

\subsection{Total RNA Isolation and Preparation of $c D N A$}

Total RNA was extracted from the cells using an ABI 6100 Nucleic Acid PrepStation and chemicals according to the manufacturer's protocol (Applied Biosystems, Foster City, CA, USA). The ratio of $\mathrm{A}_{260} / \mathrm{A}_{280}$ (purity of RNA) was in the range 1.8-2.0. RNA concentrations were determined from the absorbance $\mathrm{A}_{260}$. RNA was isolated and stored at $-80^{\circ} \mathrm{C}$. One microgram of total RNA was reverse-transcribed using the Applied Biosystems' High-Capacity cDNA Archive Kit.

\subsection{Quantitative Real Time RT-PCR Analysis}

To assess relative gene expression in C6 glioma and SH-SY5Y neuroblastoma cells, quantitative real time RT-PCR analysis was performed with an Applied Biosystems Prism 7500 Fast Sequence Detection System, using TaqMan ${ }^{\circledR}$ Universal PCR Master Mix according to the manufacturer's specifications (Applied Biosystems, Foster City, CA, USA). The validated TaqMan ${ }^{\circledR}$ probes and primers for $\mathrm{A}_{1}$ (Hs00181231_m1), A $2 \mathrm{An}$ 00583935_m1, Hs00169123_m1), A 2B (Rn00567697_m1, Hs00386497_m1), $\mathrm{A}_{3}$ (Rn00563680_m1), and $\beta$-actin (Rn00667869_m1, Hs99999903_m1) were assay-on-demand gene expression products (Applied Biosystems). The TaqMan ${ }^{\circledR}$ Gene Expression Assays have an efficiency of 1.0, which means the doubling of the PCR product in every cycle is guaranteed. The TaqMan ${ }^{\circledR}$ primer and probe sequences are packaged together in a 20X solution. The sequences are proprietary, so they are not available. The gene-specific probes were labelled using the reporter dye FAM. A non-fluorescent quencher and the minor groove binder were linked at the $3^{\prime}$ end of the probes as quenchers. The thermal cycler conditions were as follows: $20 \mathrm{~s}$ at $95^{\circ} \mathrm{C}$, followed by two steps of PCR for 40 cycles at $95^{\circ} \mathrm{C}$ for $3 \mathrm{~s}$, followed by $60^{\circ} \mathrm{C}$ for $30 \mathrm{~s}$. The levels of RNA expression were determined using the 7500 Fast System SDS software version 1.3.1 (Applied Biosystems, Foster City, CA, USA) according to the $2^{-\Delta \Delta C t}$ 
method. Then, the gene expression results were normalized to endogenous control $\beta$-actin relative to a calibrator, consisting of the mean expression level of the receptor gene as follows: $2^{-\Delta \Delta \mathrm{Ct}}=2$ $-((\mathrm{Ct}$ receptor gene $-\mathrm{Ct}$ actin) sample - (Ct receptor gene $-\mathrm{Ct}$ actin) calibrator) $\beta$-actin is an appropriated endogenous control, as its expression did not change after beer and oxidant stress treatments. The results are from three or four independent assays, performed in different plates, each using different cDNAs from the cultures analyzed, and were averaged to produce a single mean value for each mRNA.

\subsection{Radioligand Binding Assays}

\subsubsection{Adenosine $\mathrm{A}_{1}$ Receptor in $\mathrm{C} 6$ and SH-SY5Y Cells}

Adenosine $A_{1}$ receptor $\left(A_{1} R\right)$ in $C 6$ and $S H-S Y 5 Y$ cells was quantified by radioligand binding assay using $\left[{ }^{3} \mathrm{H}\right]-\mathrm{DPCPX}$, a selective $\mathrm{A}_{1} \mathrm{R}$ antagonist, as a radioligand (Amersham Biosciences, Buckinghamshire, UK), as described previously [44]. $\left[{ }^{3} \mathrm{H}\right]-\mathrm{DPCPX}$ was used at the saturating concentration of $20 \mathrm{nM}$, and $4 \mathrm{mM} \mathrm{CPA}$, a selective agonist of $\mathrm{A}_{1} \mathrm{R}$, was employed to obtain non-specific binding. The cells were previously treated with $5 \mathrm{U} / \mathrm{mL}$ adenosine deaminase (ADA) for $30 \mathrm{~min}$ at $37{ }^{\circ} \mathrm{C}$ in order to remove endogenous adenosine. Then, the cells were incubated with $\left[{ }^{3} \mathrm{H}\right]-\mathrm{DPCPX}$ for $2 \mathrm{~h}$ at $25^{\circ} \mathrm{C}$ without shaking. After this time, the cells were washed with ice-cold culture medium, lysed with $0.2 \%$ SDS, and transferred to vials to count radioactivity. Two wells from each plate were employed for protein content measurement. Radioactivity measurements in vials were performed in the Microbeta Trilux Jet scintillation counter (Perkin Elmer) using Optiphase HiSafe scintillation liquid (Perkin Elmer).

\subsubsection{Adenosine $A_{2 A}$ Receptor in SH-SY5Y Cells}

Adenosine $A_{2 A}$ receptor $\left(A_{2 A} R\right)$ was assayed in intact SH-SY5Y cells by a radioligand binding assay using $\left[{ }^{3} \mathrm{H}\right] \mathrm{ZM} 241385$ as a specific radioligand. Cells grown in 24-well plates were incubated with a saturating concentration of $\left.40 \mathrm{nM} \mathrm{[}{ }^{3} \mathrm{H}\right]-\mathrm{ZM} 241385$, as described earlier [45]. ADA (5 U/mL) was used to remove endogenous adenosine. Theophylline $(5 \mathrm{mM})$ was used to obtain non-specific binding. After $2 \mathrm{~h}$ at $25^{\circ} \mathrm{C}$, the cells were washed with ice-cold culture medium, lysed with $0.2 \%$ SDS, and transferred to vials to count radioactivity. Two wells from each plate were employed for protein content measurement. Radioactivity measurements in vials were performed in the Microbeta Trilux Jet scintillation counter (Perkin Elmer) using Optiphase HiSafe scintillation liquid (Perkin Elmer).

\subsection{Protein Determination}

Protein concentration was measured by the method of Lowry, using serum albumin as a standard [46].

\subsection{Statistical and Data Analysis}

Data are means \pm SEM. Statistical analysis was performed using Student's $t$-test and one-way ANOVA (Analysis of Variance) followed by Tukey's post-hoc test for multiple-comparison analysis. Differences between mean values were considered statistically significant at $p<0.05$ using GraphPad Prism 7.0 (GraphPad Software, San Diego, CA, USA).

\section{Results}

\subsection{Effect of Beer Extracts on C6 and SH-SY5Y Cell Viability}

Cell viability was studied in two different models, rat astroglioma C6 and human neuroblastoma SH-SY5Y cells, in order to compare possible differences between these cell types. The cells were treated for $24 \mathrm{~h}$ with three different beer extracts corresponding to dark beer (DB), non-alcoholic beer (NAB), and lager beer (LB). The procedure to obtain these extracts is described in Materials and Methods. 
C6 (Figure 1a) and SH-SY5Y (Figure 1b) cells viability was not significantly altered by the treatment with the beer extracts.

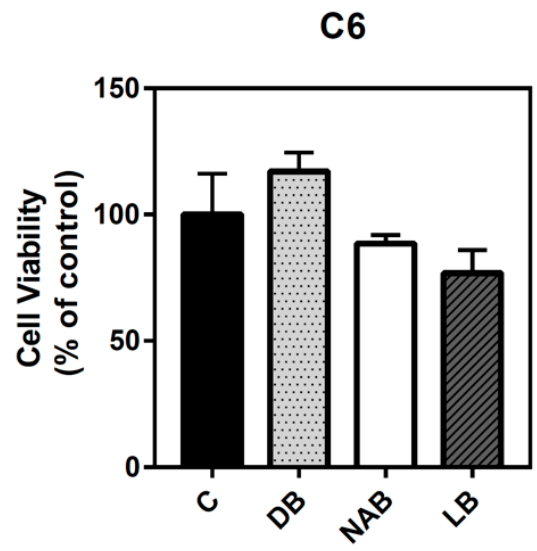

(a)

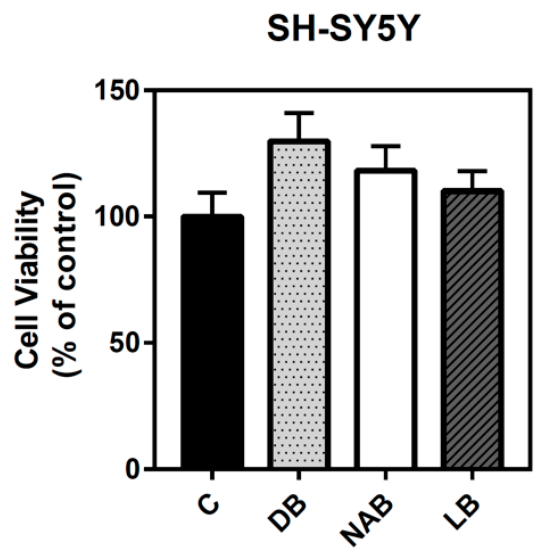

(b)

Figure 1. Effect of different beer extracts on C6 and SH-SY5Y cell viability. Dark beer (DB), non-alcoholic beer (NAB), and lager beer (LB) extracts were added to C6 (a) and SH-SY5Y (b) cells for $24 \mathrm{~h}$. Data are means \pm SEM of, at least, three independent assays. Differences were not statistically significant according to Student's $t$ test or one-way ANOVA.

\subsection{Effect of Beer Extracts on Adenosine Receptor Gene Expression in C6 and SH-SY5Y Cells}

After RNA isolation, real-time PCR assays were performed in order to know whether the beer extracts modulated adenosine receptors' gene expression. The treatments with $\mathrm{DB}(p<0.05), \mathrm{NAB}$ $(p<0.05)$, and LB $(p<0.01)$ significantly increased $\mathrm{A}_{2 \mathrm{~A}}$ gene expression (Figure $\left.2 \mathrm{a}\right)$ in $\mathrm{C} 6$ cells. This higher expression was also detected in SH-SY5Y cells exposed to DB $(p<0.05)$ or LB $(p<0.05)$ (Figure $2 b$ ). $A_{2 B}$ expression was also increased in $\mathrm{C} 6$ cells with the exposure to the beer extracts, being greater in cells exposed to NAB $(p<0.05)$ and LB $(p<0.001)$ than in those exposed to DB $(p<0.05)$ (Figure 2c). On the contrary, DB and LB extracts significantly $(p<0.05)$ decreased $A_{2 B}$ gene expression in the cells, and a lower but not statistically significant expression was observed after treatment with NAB treatment (Figure $2 \mathrm{~d}$ ). $\mathrm{A}_{3}$ gene expression was only significantly increased by $\mathrm{NAB}(p<0.05)$ in $\mathrm{C} 6$ cells (Figure 2e). In SH-SY5Y cells, $\mathrm{A}_{1}$ gene expression was decreased by the exposure to DB and LB $(p<0.01)$ (Figure 2f). Unfortunately, we could not amplify neither $\mathrm{A}_{1}$ expression in $\mathrm{C} 6$ nor $\mathrm{A}_{3}$ expression in SH-SY5Y cells under our experimental conditions. 


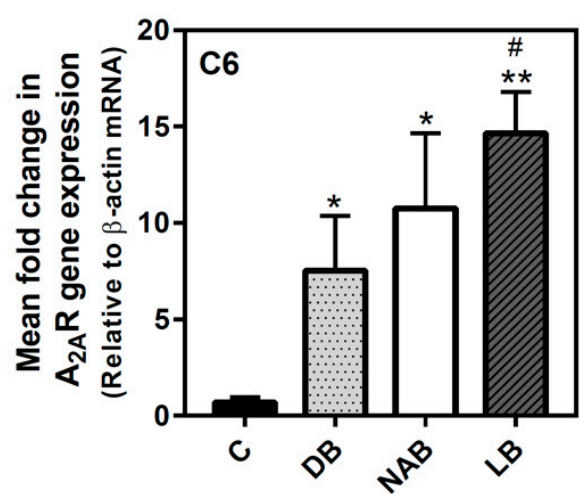

(a)

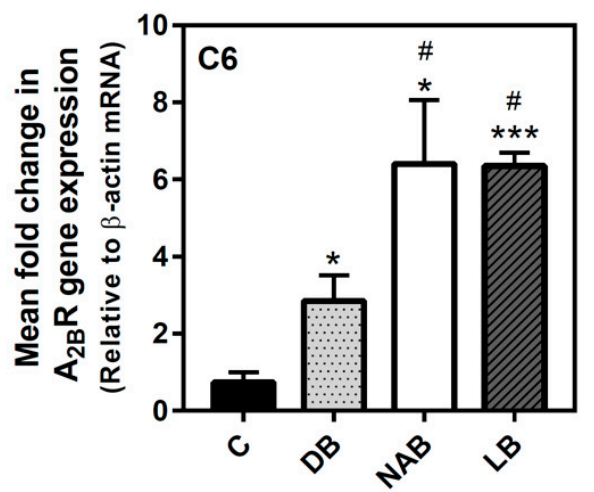

(c)

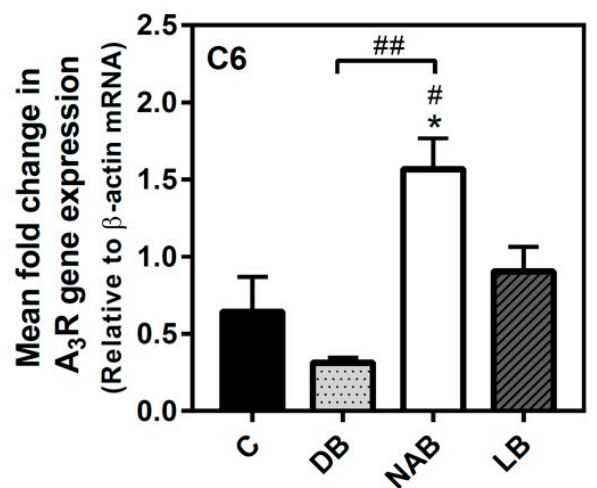

(e)

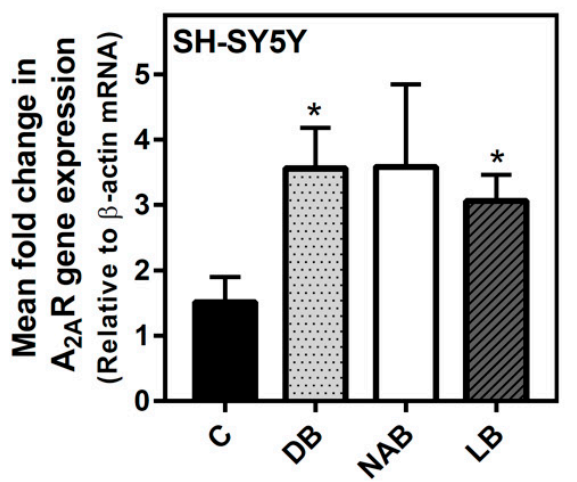

(b)

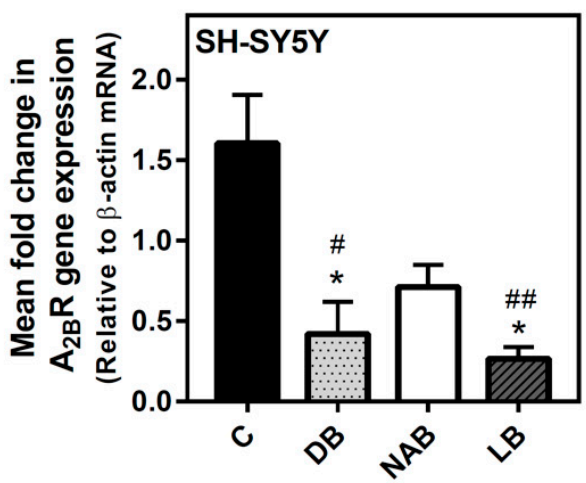

(d)

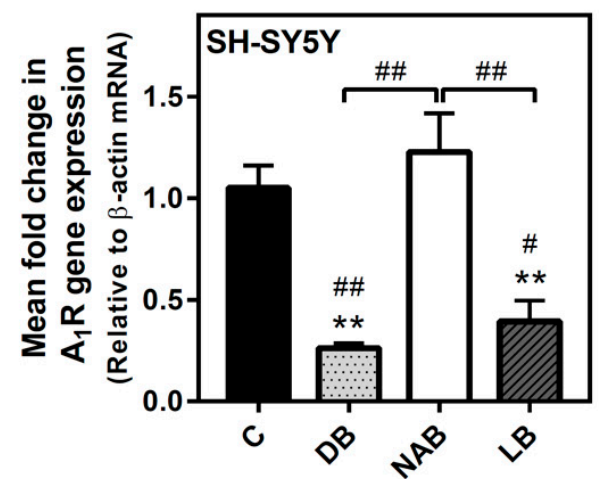

(f)

Figure 2. Cont. 


\section{C6 glioma}

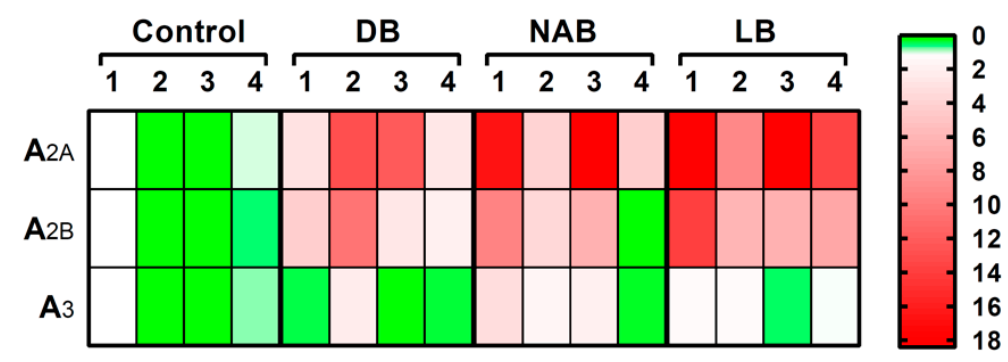

SH-SY5Y

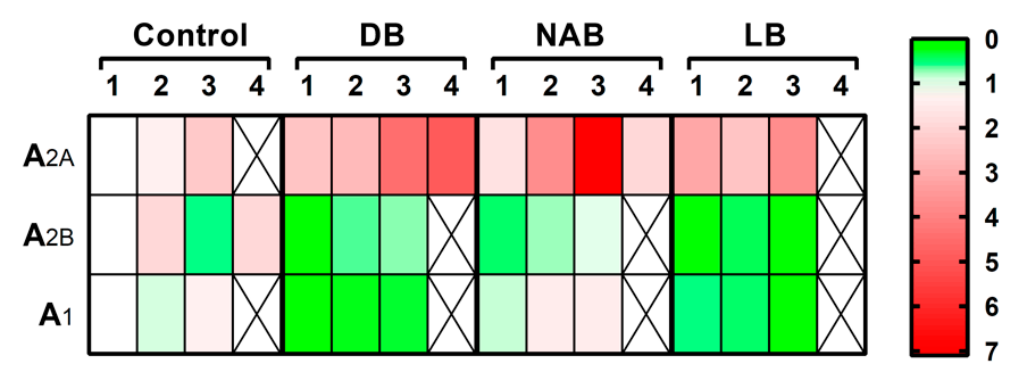

(g)

Figure 2. Adenosine receptors gene expression assayed by quantitative real-time RT-PCR in C6 and SH-SY5Y cells. After total RNA isolation, $\mathrm{A}_{2 \mathrm{~A}}$ (panels a and b), $\mathrm{A}_{2 \mathrm{~B}}$ (panels $\mathrm{c}$ and d), $\mathrm{A}_{3}$ (panel e), and $A_{1}$ (panel f) receptor gene expression levels were detected by using TaqMan universal PCR following the protocol indicated in "Materials and Methods". $\beta$-actin was used as an endogenous control in all assays. The treatments were performed for $24 \mathrm{~h}$ with DB, NAB, and LB extracts in C6 (a,c,e) and SH-SY5Y $(\mathbf{b}, \mathbf{d}, \mathbf{f})$ cells. (g) Heatmap of gene expression levels obtained from the analyzed samples. Data are means \pm SEM of, at least, three independent assays; ${ }^{*} p<0.05$, ${ }^{* *} p<0.01$, and ${ }^{* * *} p<0.001$, significantly different from their corresponding control (C) according to Student's $t$ test; \# $p<0.05$, and \#\# $p<0.01$, significantly different from control $(\mathrm{C})$ or considered bars according to one-way ANOVA test.

\subsection{Effect of Beer Extracts on Adenosine $A_{1}$ and $A_{2 A}$ Receptors Levels}

As one of the main adenosine receptors expressed and modulated in these cells according to our previous results are $\mathrm{A}_{1}$ receptors, the next step was to quantify these receptors in both C6 and SH-SY5Y cells by radioligand binding assays. All extracts of beer significantly increased adenosine $A_{1}$ receptor level in both C6 (Figure 3a) and SH-SY5Y (Figure 3b) intact cells after $24 \mathrm{~h}$ of exposure. However, DB produced the highest and most significant increase (C6: $p<0.0001$, and SH-SY5Y: $p<0.05$ ) of these receptors, followed by LB (C6: $p<0.05$, and SH-SY5Y: $p<0.05)$ and NAB (C6: $p<0.05$, and SH-SY5Y: $p<0.01)$. 
C6

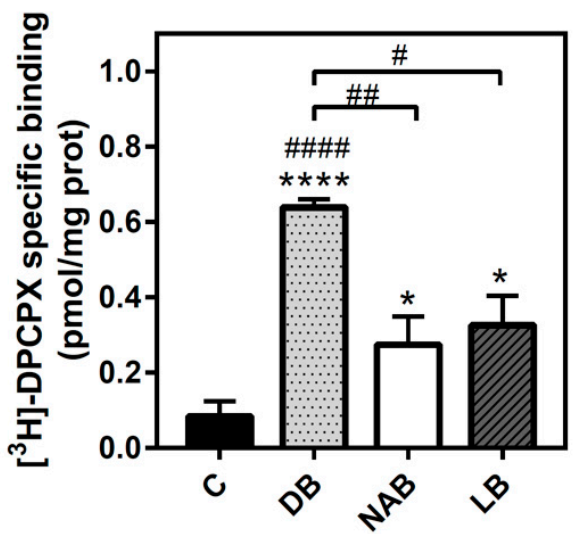

(a)

\section{SH-SY5Y}

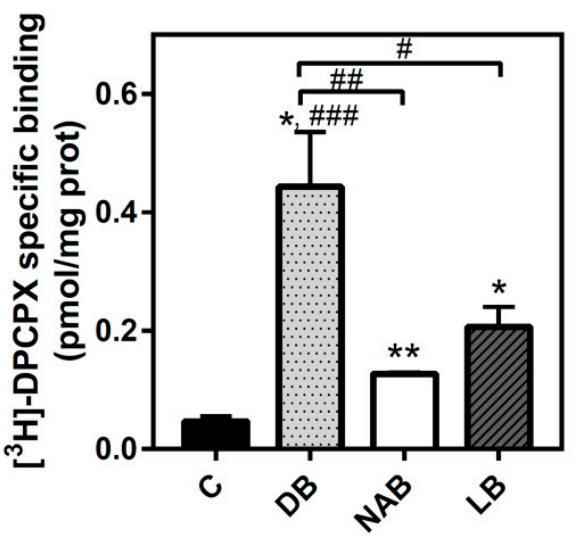

(b)

Figure 3. Analysis of adenosine $A_{1}$ receptors by radioligand binding assay in C6 and SH-SY5Y cells. Specific binding to $A_{1}$ receptors was determined in C6 (panel a) or SH-SY5Y (panel b) intact cells at saturating concentration $(20 \mathrm{nM})$ of $\left[{ }^{3} \mathrm{H}\right]-\mathrm{DPCPX}$, as described in "Materials and Methods". Nonspecific binding was determined in the presence of $4 \mathrm{mM} \mathrm{CPA}$. The treatments were performed for $24 \mathrm{~h}$ with $\mathrm{DB}, \mathrm{NAB}$, and LB extracts. Data are means \pm SEM of, at least, three independent assays; ${ }^{*} p<0.05$, ** $p<0.01$, and ${ }^{* * * *} p<0.0001$, significantly different from their corresponding control (C) according to Student's $t$ test; $\# p<0.05$, \#\# $p<0.01$, \#\#\# $p<0.001$, and \#\#\#\# $p<0.0001$, significantly different from control (C) or considered bars according to one-way ANOVA test.

Adenosine $\mathrm{A}_{2 \mathrm{~A}}$ receptor was also quantified in SH-SY5Y intact cells. The NAB extract was the only one able to significantly increase the level of these receptors after $24 \mathrm{~h}$ of exposure (Figure 4).

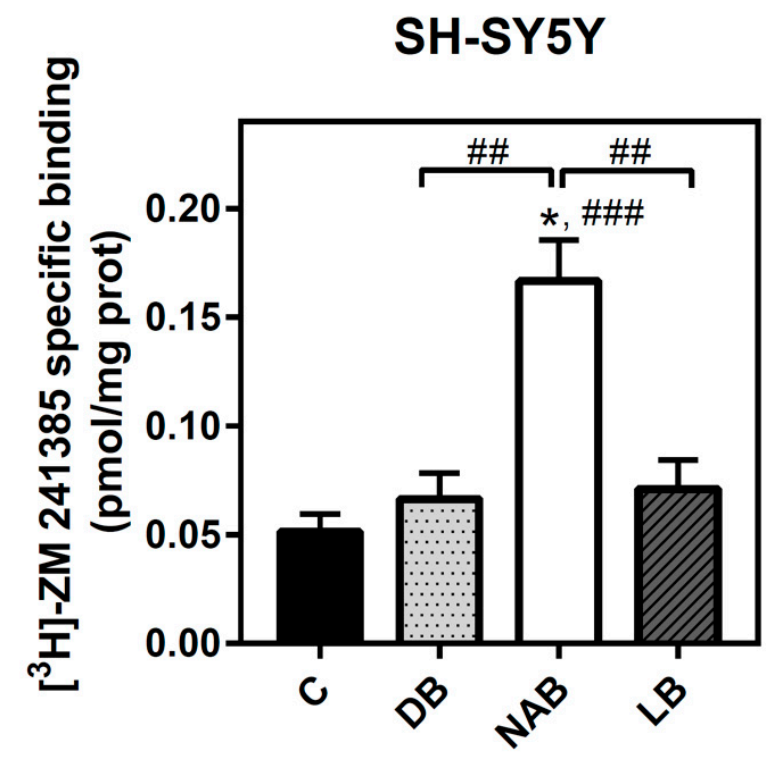

Figure 4. Analysis of adenosine $\mathrm{A}_{2 \mathrm{~A}}$ receptors by radioligand binding assay in SH-SY5Y cells. Specific binding to $\mathrm{A}_{2 \mathrm{~A}}$ receptor was determined in intact cells at saturating concentration $(40 \mathrm{nM})$ of $\left[{ }^{3} \mathrm{H}\right]-\mathrm{ZM}$ 241385, as described in "Materials and Methods". Nonspecific binding was determined in the presence of $12 \mathrm{mM}$ theophylline. Treatments were performed for $24 \mathrm{~h}$ with DB, NAB, and LB extracts in SH-SY5Y cells. Data are means \pm SEM of, at least, three independent assays; ${ }^{*} p<0.05$ significantly different from their corresponding control (C) according to Student's $t$ test; \#\# $p<0.01$ and \#\#\# $p<0.001$, significantly different from control $(\mathrm{C})$ or considered bars according to one-way ANOVA test. 


\subsection{Antioxidant Ability of Beer Extracts in C6 and SH-SY5Y Cells}

The antioxidant ability of beers was proved for short $(30 \mathrm{~min})$ and long $(24 \mathrm{~h})$ times. To this end, hydrogen peroxide $\left(50 \mu \mathrm{M} \mathrm{H}_{2} \mathrm{O}_{2}\right)$ treatment was chosen as the oxidative stress agent. One-way ANOVA analysis revealed that this compound significantly reduced $\mathrm{C} 6$ cells viability at both times of treatment (Figure $5 a, p<0.01$ and $5 b, p<0.0001$ ), and the effect of cell death was more accentuated at $24 \mathrm{~h}$. Although similar profiles were observed in all cases, the antioxidant ability (i.e., the reduction of cell viability decrease elicited by $\mathrm{H}_{2} \mathrm{O}_{2}$ ) was more potent and significant for DB extracts at $24 \mathrm{~h}$ (Figure $5 b, p<0.001$ ) and at $30 \mathrm{~min}$ (Figure $5 \mathrm{a}, p<0.01$ ).

Similarly, $\mathrm{H}_{2} \mathrm{O}_{2}$ also reduced SH-SY5Y cells viability at $30 \min$ (Figure $5 c, p<0.0001$ ) and $24 \mathrm{~h}$ (Figure $5 \mathrm{~d}, p<0.0001$ ), and the effect of cell death was more accentuated at $24 \mathrm{~h}$. At $30 \mathrm{~min}$, DB extract caused again the most potent antioxidative effect $(p<0.0001)$ (Figure $5 c)$. Increasing the exposure time to $24 \mathrm{~h}$, a similar profile was observed: DB $(p<0.0001)$, LB $(p<0.01)$, and NAB $(p<0.05)$ extracts recovered cell viability with respect to hydrogen peroxide (Figure $5 d$ ), showing again an antioxidant and protective effect. Interestingly, DB extract showed the highest antioxidant ability at both times and for both cell types analyzed.

In agreement with a possible participation of adenosine receptors in the protective effect of DB, the presence of several adenosine receptors antagonists significantly reduced cell viability measured in the presence of $\mathrm{H}_{2} \mathrm{O}_{2}$ and DB at $30 \mathrm{~min}$ (Figure 5e) and at $24 \mathrm{~h}$ (Figure 5f) in C6 glioma cells. 


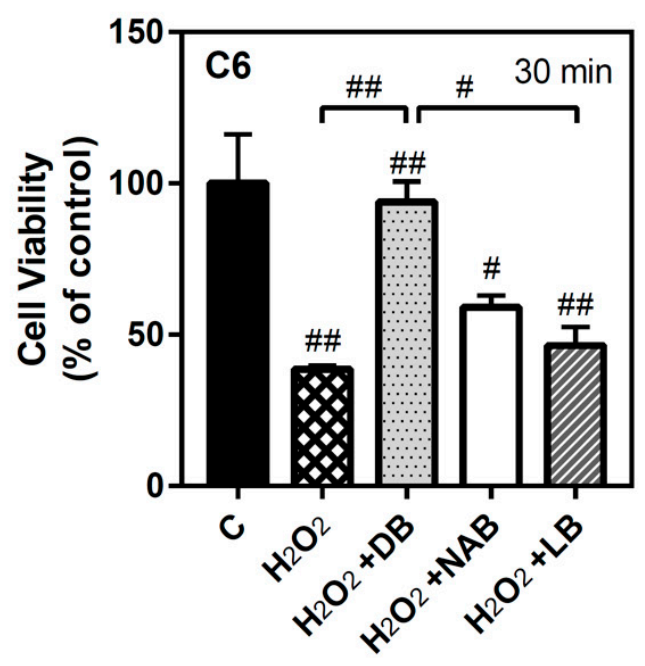

(a)

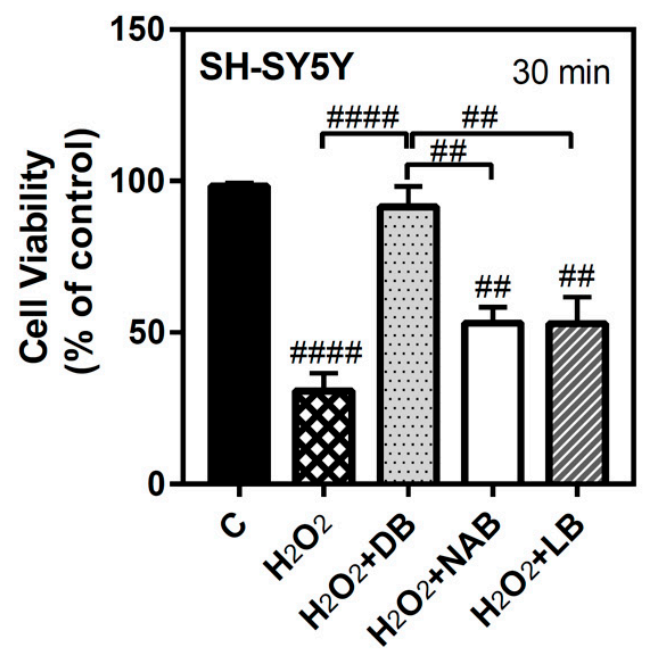

(c)

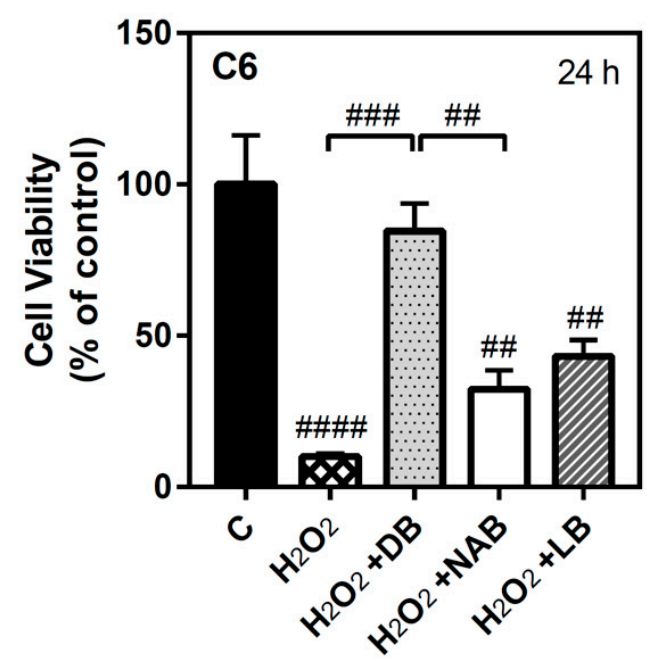

(b)

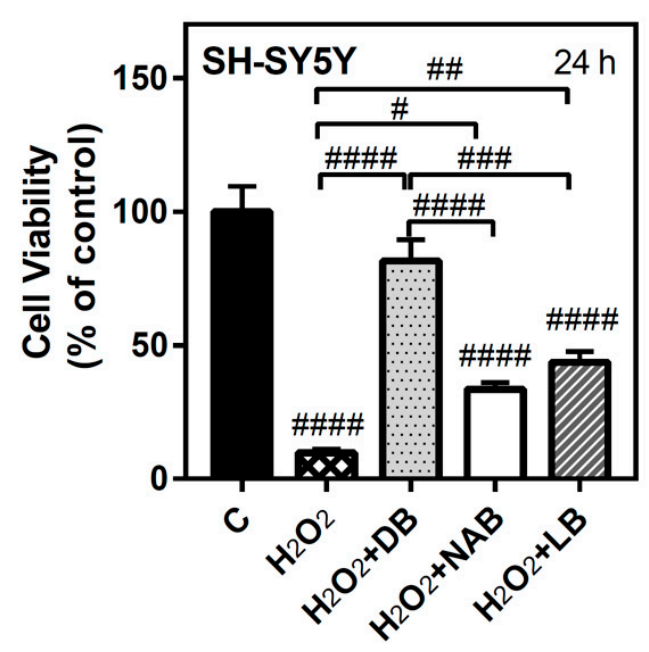

(d)

Figure 5. Cont. 


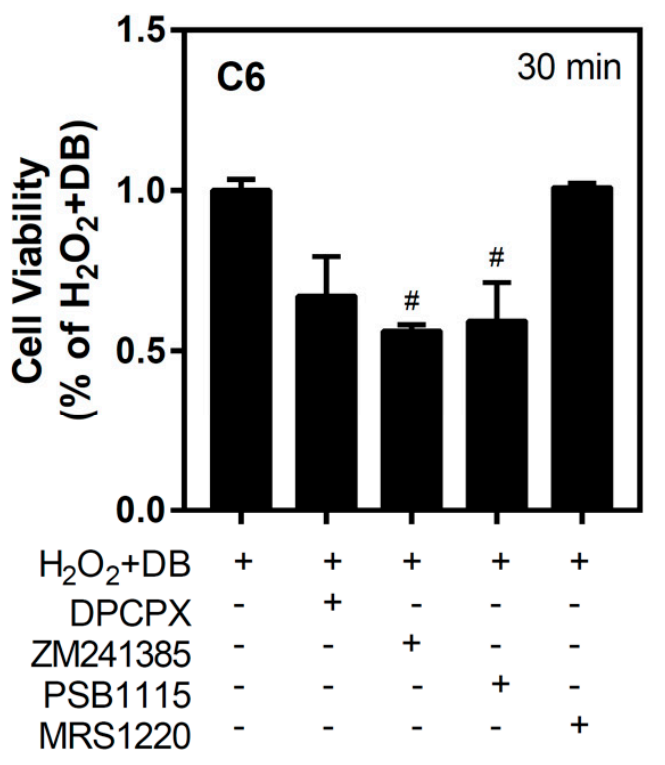

(e)

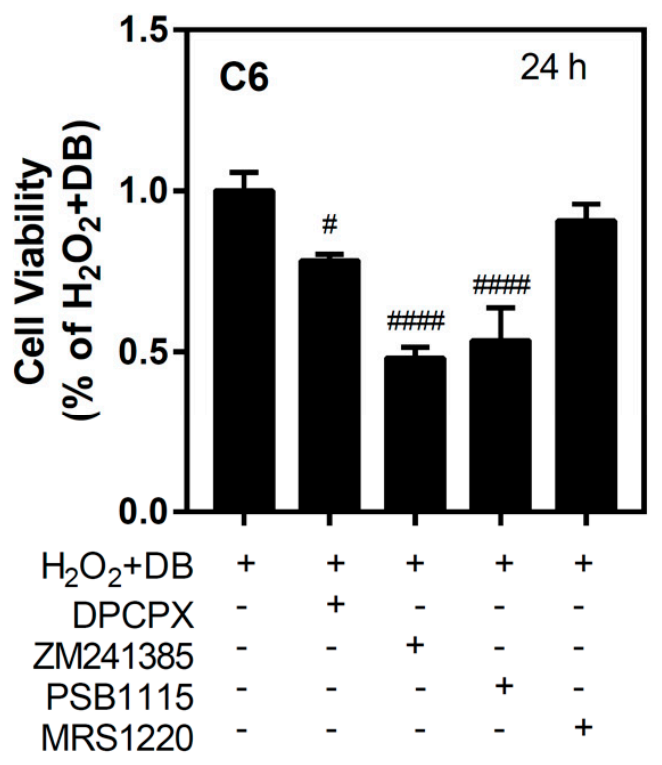

(f)

Figure 5. Effect of different beer extracts on cell viability in the presence of the oxidative stress induced by hydrogen peroxide $\left(\mathrm{H}_{2} \mathrm{O}_{2}\right)$ in $\mathrm{C} 6$ and SH-SY5Y. Treatments were performed for $30 \mathrm{~min}$ and $24 \mathrm{~h}$ with $50 \mu \mathrm{M} \mathrm{H}_{2} \mathrm{O}_{2}$ and DB, NAB, and LB extracts in C6 (panels a and $\mathbf{b}$ ) and SH-SY5Y (panels $\mathbf{c}$ and d) cells. Effect of $10 \mu \mathrm{M} \mathrm{DPCPX}, 100 \mu \mathrm{M}$ ZM241385, $100 \mu \mathrm{M}$ PSB1115, and $10 \mu \mathrm{M}$ MRS1220, specific adenosine $A_{1}, A_{2 A}, A_{2 B}$, and $A_{3}$ receptor antagonists, respectively, in the presence of $50 \mu \mathrm{M} \mathrm{H}_{2} \mathrm{O}_{2}$ and DB (panel e and f). Data are means \pm SEM of, at least, three independent assays; \# $p<0.05, \# \# p<0.01$, $\# \# \# p<0.001$, and \#\#\#\# $p<0.0001$, significantly different from control (C) or considered bars according to one-way ANOVA test.

\subsection{Effect of Beer Extracts and Oxidative Stress on Adenosine Receptors Gene Expression in C6 and SH-SY5Y Cells}

In order to assess the possible involvement of adenosine receptors in the antioxidative effect evoked by beer, we tried to analyze the gene expression of these receptors during treatment. However, for long exposure time ( $24 \mathrm{~h}$ ), we were unable to reliably detect adenosine receptors expression in C6 cells under our experimental conditions, probably because of the very low yield of total RNA extraction achieved after $\mathrm{H}_{2} \mathrm{O}_{2}$ treatment, whereas it could be determined in SH-SY5Y cells. Adenosine $\mathrm{A}_{2 \mathrm{~A}}$ receptors gene expression in $\mathrm{C} 6$ cells was not modified by hydrogen peroxide, but the combination of LB with this compound significantly increased gene expression at $30 \mathrm{~min}$ of treatment with respect to the control and $\mathrm{H}_{2} \mathrm{O}_{2}$ values ( $p<0.05$, both) (Figure 6a). In the same way, $\mathrm{A}_{2 \mathrm{~B}}$ gene expression was not affected by $\mathrm{H}_{2} \mathrm{O}_{2}$ exposure, but it was significantly increased by $\mathrm{LB}$ and $\mathrm{H}_{2} \mathrm{O}_{2}$ with respect to the control $(p<0.01)$ and $\mathrm{H}_{2} \mathrm{O}_{2}(p<0.001)$ cases at 30 min of treatment (Figure 6b). However, the combination of DB with $\mathrm{H}_{2} \mathrm{O}_{2}$ significantly $(p<0.05)$ decreased $\mathrm{A}_{3}$ gene expression with respect to $\mathrm{H}_{2} \mathrm{O}_{2}$ treatment at $30 \mathrm{~min}$ (Figure $6 \mathrm{c}$ ). In general, the gene expression profiles of $\mathrm{A}_{2 \mathrm{~A}}, \mathrm{~A}_{2 \mathrm{~B}}$, and $\mathrm{A}_{3}$ after combined treatments of $\mathrm{H}_{2} \mathrm{O}_{2}$ and beer extracts were similar to those detected at $24 \mathrm{~h}$ in cells treated with the extracts alone (Figure 2a,c,e), confirming the absence of gene expression modulation by $\mathrm{H}_{2} \mathrm{O}_{2}$ in $\mathrm{C} 6$ cells at $30 \mathrm{~min}$. 


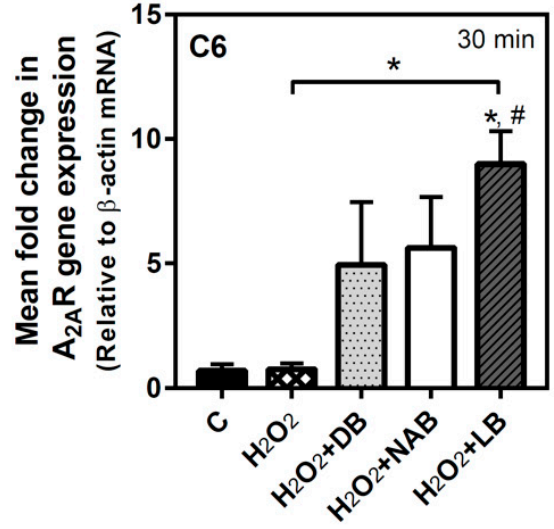

(a)

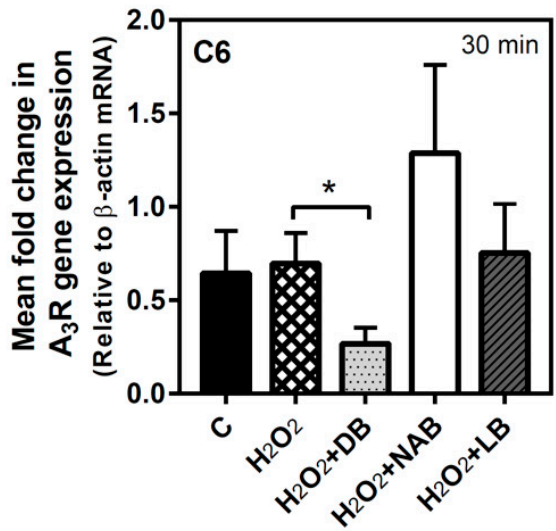

(c)

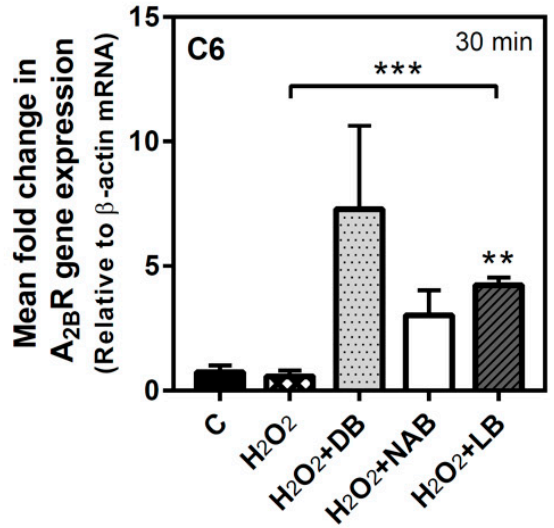

(b)

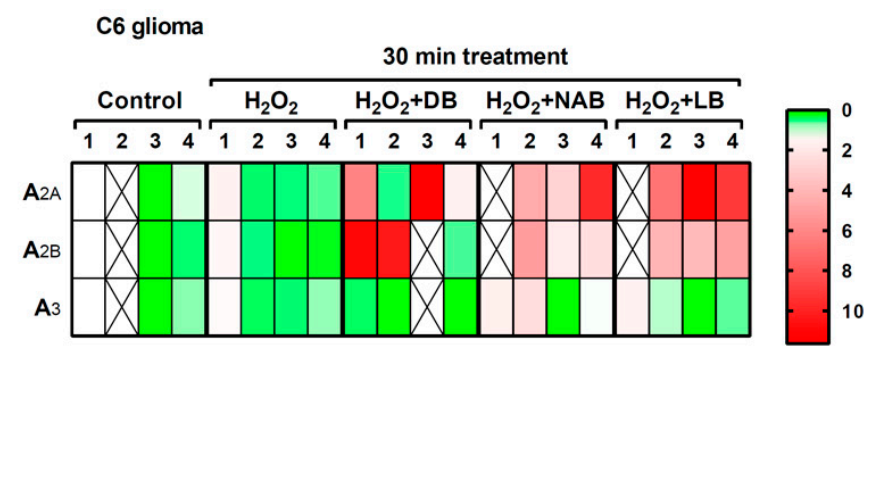

(d)

Figure 6. Adenosine receptors gene expression assayed by quantitative real-time RT-PCR in C6 cells. After total RNA isolation, $A_{2 A}$ (panel a), $A_{2 B}$ (panel b), and $A_{3}$ (panel c) receptor gene expression levels were detected by TaqMan universal PCR following the protocol indicated in "Materials and Methods". $\beta$-actin was used as an endogenous control in all assays. Treatments were performed for 30 min with $50 \mu \mathrm{M}$ hydrogen peroxide $\left(\mathrm{H}_{2} \mathrm{O}_{2}\right)$ and $\mathrm{DB}, \mathrm{NAB}$, and LB extracts in C6 cells. (d) Heatmap of gene expression levels obtained in the analyzed samples. Data are means \pm SEM of, at least, three independent assays; ${ }^{*} p<0.05,{ }^{* *} p<0.01$, and ${ }^{* * *} p<0.001$, significantly different from their corresponding control (C) or considered bars according to Student's $t$ test; \# $p<0.05$ significantly different from control $(\mathrm{C})$ according to one-way ANOVA test.

In SH-SY5Y cells, adenosine receptors gene expression after $\mathrm{H}_{2} \mathrm{O}_{2}$ exposure was only significantly modified in the case of $\mathrm{A}_{2 \mathrm{~B}}$ receptor gene, which was decreased at both times analyzed. $\mathrm{A}_{1}$ gene expression was significantly decreased by the combination of $\mathrm{DB}$ and $\mathrm{H}_{2} \mathrm{O}_{2}$ with respect to the control and oxidative stress conditions ( $p<0.01$ and $p<0.001$, respectively) at 30 min of treatment (Figure 7a). At $24 \mathrm{~h}, \mathrm{~A}_{1}$ gene expression was significantly decreased by DB and LB with $\mathrm{H}_{2} \mathrm{O}_{2}$ treatment with respect to the control cases $(p<0.05)$, while $\mathrm{H}_{2} \mathrm{O}_{2}$ alone had no effect (Figure $7 \mathrm{~b}$ ). $\mathrm{A}_{2 \mathrm{~A}}$ gene expression was not modified at $30 \mathrm{~min}$ (Figure 7c) or $24 \mathrm{~h}$ treatment (Figure 7d). In turn, $\mathrm{A}_{2 \mathrm{~B}}$ gene expression was significantly decreased in all conditions assayed ( $p<0.05$, each one) at 30 min exposure (Figure 7e). Similar results were obtained at $24 \mathrm{~h}$ of treatment ( $p<0.05$, each one) with respect to the control cases (Figure 7f), although no significant differences were observed between treatment with $\mathrm{H}_{2} \mathrm{O}_{2}$ and treatment with $\mathrm{H}_{2} \mathrm{O}_{2}$ plus beer extracts. 


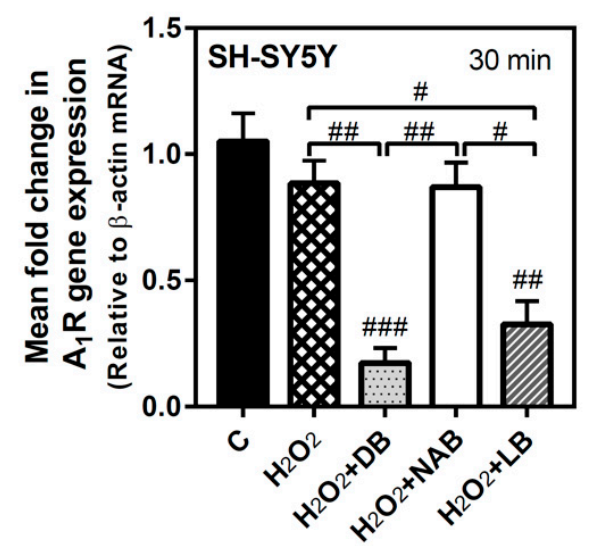

(a)

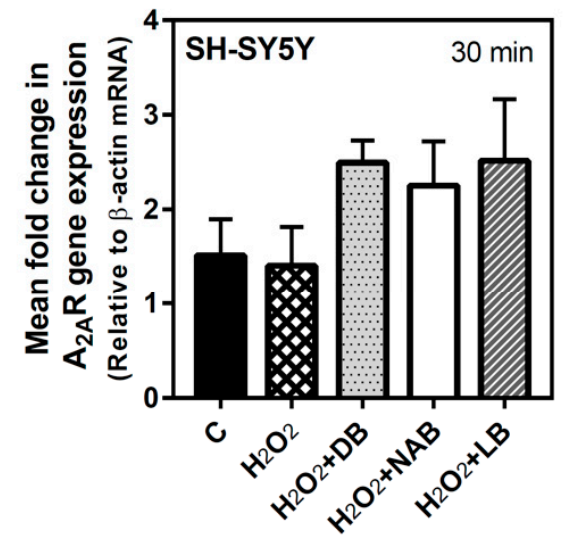

(c)

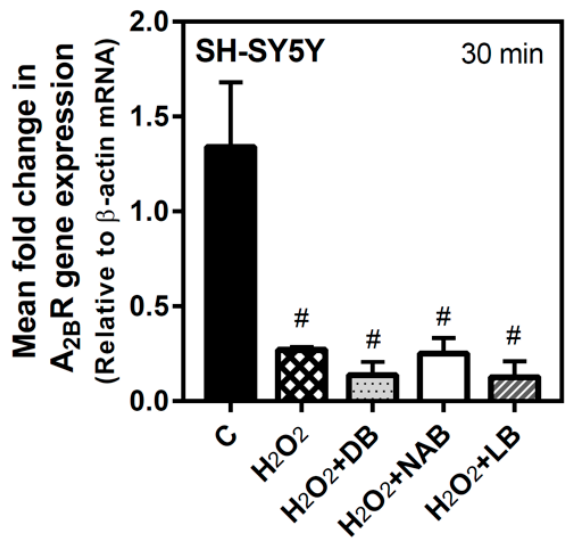

(e)

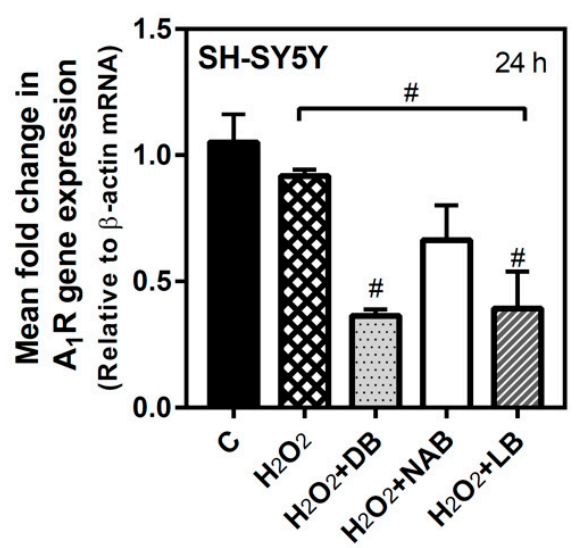

(b)

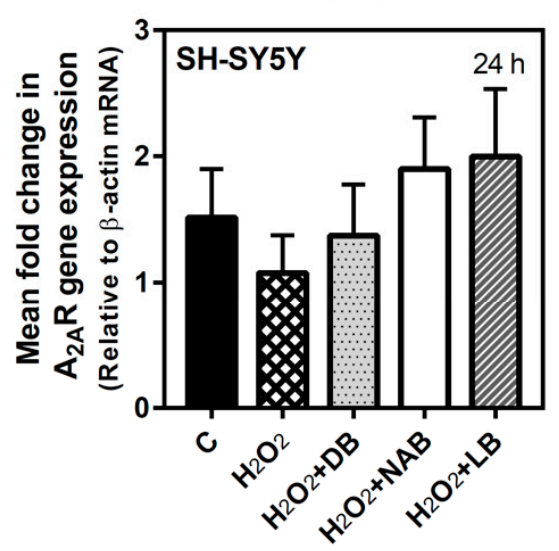

(d)

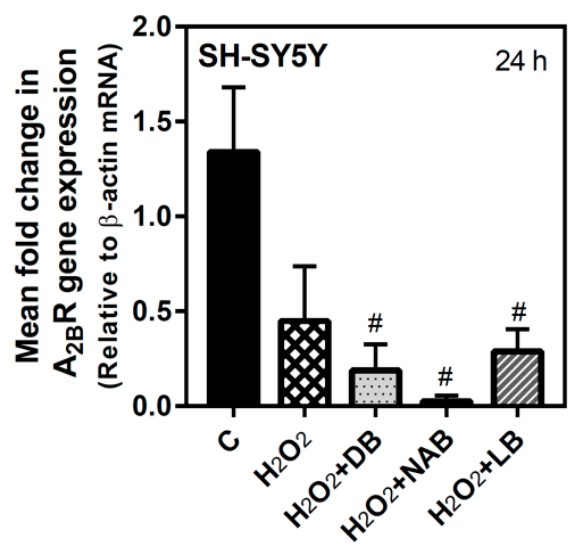

(f)

Figure 7. Cont. 
SH-SY5Y

30 min treatment

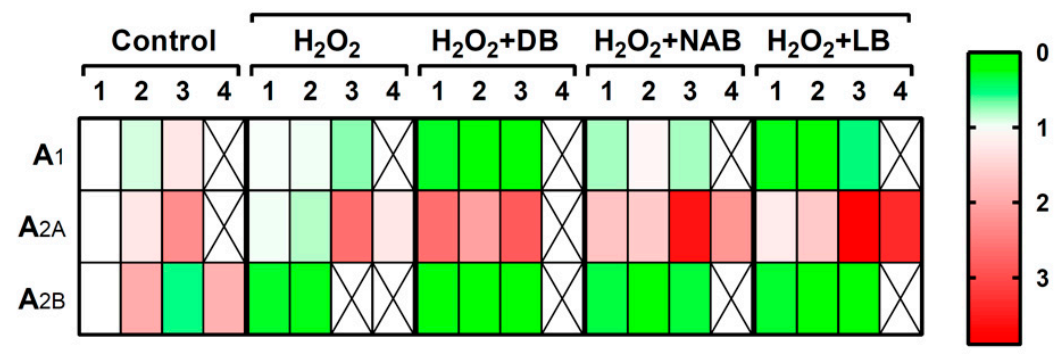

SH-SY5Y

$24 \mathrm{~h}$ treatment

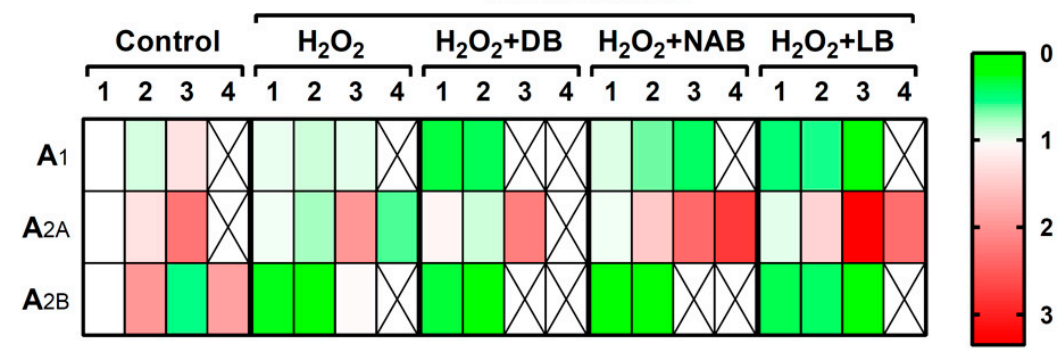

(g)

Figure 7. Adenosine receptors gene expression assayed by quantitative real-time RT-PCR in SH-SY5Y cells. After total RNA isolation, $A_{1}$ (panels a and $\mathbf{b}$ ), $A_{2 A}$ (panels $\mathbf{c}$ and $\mathbf{d}$ ), and $A_{2 B}$ (panels e and $\mathbf{f}$ ) gene expression levels were detected by TaqMan universal PCR following the protocol indicated in "Materials and Methods". $\beta$-actin was used as an endogenous control in all assays. Treatments were performed for $30 \mathrm{~min}(\mathbf{a}, \mathbf{c}, \mathbf{e})$ and $24 \mathrm{~h}(\mathbf{b}, \mathbf{d}, \mathbf{f})$ with $50 \mu \mathrm{M}$ hydrogen peroxide $\left(\mathrm{H}_{2} \mathrm{O}_{2}\right)$ and DB, NAB, and LB extracts in SH-SY5Y cells. (g) Heatmap of gene expression levels obtained in the analyzed samples. Data are means \pm SEM of, at least, three independent assays; \# $p<0.05$, \#\# $p<0.01$, and \#\#\# $p$ $<0.001$, significantly different from control (C) or considered bars according to one-way ANOVA test.

\section{Discussion}

A moderate consumption of certain low-alcohol beverages, as wine and beer, could have beneficial properties for our health, showing a protective effect even on AD [47-49]. Oxidative stress is involved in neurodegenerative pathologies [50-52] and could be fought by the antioxidant ability of beer [5]. Our results show the different effects of beers (dark, non-alcoholic, and lager) in cells (C6 and SH-SY5Y) and the protection by these beers' extracts against oxidative stress. The modulation of adenosine receptors gene expression and protein levels could be related to this antioxidative effect of beer.

Although several epidemiological studies indicate that the intake of certain low-alcohol beverages show beneficial effects, there is controversy about this. A frequent alcohol ingestion would increase dementia or cognitive decline as compared to a low-frequency intake [53-56]. Most of these studies involved wine or beer, and some of them associated a minor risk of dementia or AD with moderate consumption of wine [57-59]. These studies suggest polyphenols and alcohol as the possible responsible chemicals of these effects [60]. Thus, a moderate intake of beer would produce protective effects in the brain against plaques aggregation, associating these effects with the antioxidant properties of beer $[16,17]$. Other studies claim that a moderate consumption of beer increases silicon in our organism, reducing the absorption of aluminum in the digestive tract, a risk element in AD [61]. As these studies do not differentiate the effects due to alcohol from those due to other beer components, it could be suggested that the health benefits of this low-alcohol beverage probably could be related to its content in polyphenols and to its antioxidant properties.

Several authors postulate that beer ingestion protects from oxidative stress as a result of the high beer content of antioxidants [62-65]. Thus, these antioxidant compounds show protective effects in 
several experimental models. Rutin, a flavonoid glucoside present in several vegetables, is suggested as a multi-target preventive agent that may act as an adjuvant complementary molecule against oxidative stress in neuroblastoma IMR32 cells [66]. Geraniol has also showed a protective effect in SK-N-SH cells against oxidative stress induced by rotenone [67]. Other studies affirm that dietary flavonoids, specially flavonols, are associated with low rates of dementia in some countries [68].

Our results confirm the antioxidant ability of beer, as beer treatments (dark, non-alcoholic, and lager) at $24 \mathrm{~h}$ recovered cell viability in C6 and SH-SY5Y cells, avoiding cell death evoked by hydrogen peroxide. This property was reported for polyphenols present in wine, such as resveratrol, that was shown to inhibit cyclooxygenase $2(\mathrm{COX}-2)$ and decrease prostaglandin $\mathrm{E}_{2}\left(\mathrm{PGE}_{2}\right)$ in the presence of beta-amyloid peptide [69]. Moreover, procyanidins from seed grapes showed antioxidant benefits in PC-12 cells [70]. Our results show that dark beer is the treatment that presents the highest antioxidative effect, at $30 \mathrm{~min}$ and $24 \mathrm{~h}$, and is able to produce the highest increase of adenosine $\mathrm{A}_{1}$ receptor protein levels in both cells models analyzed. The differences between the three kinds of beer may be due to their different phenolic composition. In fact, dark beer seems to have a higher amount of phenolic compounds than non-alcoholic and light beers [71]. Specifically, the levels of xanthohumol, isoxanthohumol, 8-prenylnaringenin, and iso-alpha-acids are higher in dark than non-alcohol and light beers, suggesting that the phenol B ring in hydroxylated flavonoids has higher antioxidant ability than other compounds [72]. Adenosine and inosine are also present in beers [73]. Adenosine exerts its effects through four specific adenosine receptors that are able to modulate neuronal and synaptic function. Adenosine $A_{1}$ receptor is associated to neuroprotection by suppressing neural activity in presynaptic action, due to the decrease of excitatory neurotransmitters release [74], while $\mathrm{A}_{2 \mathrm{~A}}$ receptor promotes neurotransmitters release and postsynaptic depolarization. In addition, adenosine receptors modify cell responses to neurotransmitters or to other receptor agonists [75]. Adenosine receptors have been involved in several neurodegenerative diseases. It is proved that adenosine receptors' density change in $A D$ patients [75]. For example, adenosine $A_{1}$ and $A_{2 A}$ receptors were increased in the frontal cortex of AD patients [27]. Also, in the frontal cortex of Pick disease patients, adenosine $\mathrm{A}_{1}$ receptors were increased, while normal values were maintained in the occipital cortex [76]. $A_{2 A}$ receptors are also increased in the putamen of early PD [77]. Accordingly, antagonists of adenosine receptors have been related to protection and even treatment of $\mathrm{AD}$ and PD. Epidemiologic studies indicate that caffeine consumption, a non-selective antagonist of adenosine $\mathrm{A}_{2 \mathrm{~A}}$ receptors, is associated with a low risk of development of $\mathrm{AD}, \mathrm{PD}$, and dementia, decreasing the cognitive decline of aging $[38,78]$.

We must note that we worked with alcohol-free extracts of beer. In fact, cell viability was not altered by any of the beer extracts alone, confirming the absence of ethanol. Therefore, the modulation of adenosine receptors here reported could be associated with beer components other than ethanol [62]. Moreover, NAB extract modulated, in some occasions, receptor gene expression in the same way as the other extracts.

At protein level, all beer extracts increased $A_{1}$ receptor levels, considered as "protective", in C6 and SH-SY5Y cells. The quantification of $\mathrm{A}_{2 \mathrm{~A}}$ receptor was only performed in SH-SY5Y, and non-alcoholic beer increased $\mathrm{A}_{2 \mathrm{~A}}$ receptor gene expression. However, the gene expression results did not correspond to the protein levels in the cases of adenosine $A_{1}$ receptor in both cell models and of $A_{2 A}$ receptor in SH-SY5Y. These differences between gene and protein expression have been described previously $[37,79]$, suggesting different post-translational mechanisms responsible for these discrepancies.

We can suggest that the antioxidative protection of beer observed in our results is related to the increase in adenosine $A_{1}$ receptor. Dark beer was the most potent antioxidant treatment in both cell types and induced the highest increase of adenosine $A_{1}$ receptor protein levels. In agreement with this, endogenous adenosine is able to modulate oxidative stress via $A_{1}$ receptors in ischemic heart [80]. In mice, this receptor decreased coronary reactive hyperemia counteracting hydrogen peroxide production mediated by $\mathrm{A}_{2 \mathrm{~A}}$ receptors in the heart [81]. In addition, the activation of $\mathrm{A}_{1}$ receptors reduced reactive oxygen species in ventricular myocytes [82]. Adenosine receptors function and level have been involved in neuroprotective and antitumoral mechanisms in C6 cells. Thus, 
$A_{1}$ and $A_{2 A}$ receptors were found to be modulated by hypoxia [34] and glutamate excitotoxicity [37] as an attempt to protect $\mathrm{C} 6$ cells against these toxic insults. In addition, adenosine receptors have been related to $\mathrm{C} 6$ cell death processes induced by several molecules. $A_{2 A}$ receptors participate in cordycepin-induced apoptosis, p53 activation, and caspase-7 and PARP cleavage, as all of these processes were blocked by $\mathrm{A}_{2 \mathrm{~A}}$ antagonists and small-interference RNA (siRNA) knockdown of $\mathrm{A}_{2 \mathrm{~A}}$ receptors [33]. $A_{3}$ receptors activation in $\mathrm{C} 6$ cells causes apoptosis by reducing the expression of Bcl-2 [36] and also mediates the anti-proliferative action of alpha-bisabolol [83] and indomethacin [35].

Similarly, in SH-SY5Y cells, adenosine receptors have been related to neuroprotection. In fact, these cells have been used as a model to study the neuroprotective action of new partial agonists of $A_{1}$ receptors [32]. $A_{2 A}$ receptor blockade also neuroprotects these cells against neurotoxicity induced by $\alpha$-synuclein, which is involved in PD [41]. In addition, $\mathrm{A}_{1}$ and $\mathrm{A}_{2 \mathrm{~A}}$ receptors have been also involved in neuroprotection against $\beta$-amyloid peptide neurotoxicity, which is related to $\operatorname{AD}[38,40]$, and in the neuroprotective action evoked by fullerene nanoparticles against hypoxic insult [39].

The three beers analyzed herein have different organoleptic properties and probably different composition and concentration of compounds such as polyphenols, vitamins, minerals, and nucleosides, as it has been demonstrated for other beers [13,71-73]. The effects of specific compounds have been studied in other models. Resveratrol is a polyphenol present in red wine and in beer. Some of resveratrol molecular targets are estrogen receptor $\alpha$, cyclooxygenase $1, \mathrm{NF}-\mathrm{KB}$, and adenosine receptors [23,24]. Previous studies from our group showed that this polyphenol is able to modulate adenosine-mediated signaling in SAMP8 mice, a model of AD, suggesting a neuroprotective role for resveratrol, acting through adenosine receptors, against neurodegenerative diseases [43]. Moreover, adenosine receptors seems to mediate in the anti-inflammatory activity of resveratrol in astrocytes, thus exerting an important role for resveratrol-mediated glioprotection [84]. In addition, tea compounds, such as polyphenols, teanine, caffeine, and teaflavines, antagonize adenosine $\mathrm{A}_{2 \mathrm{~A}}$ receptors and exhibit neuroprotective and antioxidant properties, which could be related to decreased PD and AD risk by reduction of oxidative stress [85]. It seems clear that flavonoids have neuroprotective effects against aging in neurodegenerative diseases such as $\mathrm{AD}$ [68], and some of these compounds are present in beers.

Recently, we have reported that the polyphenol resveratrol acts as a non-selective agonist of adenosine receptors. Future research will be necessary to determine whether this or other antioxidant molecules present in beer, such as xanthohumol, are involved in the mechanism underlying adenosine receptors modulation. Also, future in vivo studies would be needed to determine the physiological effect of these antioxidant molecules in animals.

There are no studies, at least to our knowledge, about the effect of beer on adenosine receptors. This is the first time that beer extracts are reported to modulate these receptors, which are endogenously expressed in the neuronal and glial cell models used herein. In addition, this receptors' modulation could be responsible for the protective effect of beer extracts against oxidative stress. Such receptor modulation and protective effect could be of relevance in $\mathrm{AD}$, where oxidative stress and adenosine receptors have been involved.

\section{Conclusions}

In summary, this study showed that different beers (dark, non-alcoholic, and lager) have antioxidant protective properties, being dark beer the strongest antioxidant among them. These beers are also able to modulate adenosine receptors gene expression and protein levels, which could be involved, at least in part, in the protective effect of beer against oxidative stress elicited by hydrogen peroxide in two different (glioma and neuroblastoma) cell models.

Author Contributions: Conceptualization, M.M. and J.L.A.; Formal analysis, P.A.-A., M.M., and J.L.A.; Funding acquisition, M.M.; Investigation, P.A.-A.; Writing-original draft, P.A.-A. and M.M.; Writing-review \& editing, M.M. and J.L.A. 
Funding: This research was funded by Junta de Comunidades de Castilla-La Mancha (JCCM), grant number PEII-2014-030-P.

Acknowledgments: P.A-A. was the recipient of a predoctoral Manuel de Oya 2016 fellowship from Fundación Cerveza y Salud (CON170117).

Conflicts of Interest: The authors declare no conflict of interest. The funders had no role in the design of the study; in the collection, analyses, or interpretation of data; in the writing of the manuscript, or in the decision to publish the results.

\section{References}

1. Gustafson, D.R.; Clare Morris, M.; Scarmeas, N.; Shah, R.C.; Sijben, J.; Yaffe, K.; Zhu, X. New Perspectives on Alzheimer's Disease and Nutrition. J. Alzheimer's Dis. 2015, 46, 1111-1127. [CrossRef]

2. Hernando-Requejo, V. Nutrición y deterioro cognitivo. Nutrición Hospitalaria 2016, 33, 49-52. [CrossRef]

3. Airoldi, C.; Ferla, B.L.; D'Orazio, G.; Ciaramelli, C.; Palmioli, A. Flavonoids in the Treatment of Alzheimer's and Other Neurodegenerative Diseases. Curr. Med. Chem. 2018, 25, 3228-3246. [CrossRef]

4. Barberger-Gateau, P.; Jutand, M.A.; Letenneur, L.; Larrieu, S.; Tavernier, B.; Berr, C. Correlates of regular fish consumption in French elderly community dwellers: Data from the Three-City study. Eur. J. Clin. Nutr. 2005, 59, 817-825. [CrossRef]

5. Piazzon, A.; Forte, M.; Nardini, M. Characterization of Phenolics Content and Antioxidant Activity of Different Beer Types. J. Agric. Food Chem. 2010, 58, 10677-10683. [CrossRef] [PubMed]

6. Yao, J.; Zhang, B.; Ge, C.; Peng, S.; Fang, J. Xanthohumol, a Polyphenol Chalcone Present in Hops, Activating Nrf2 Enzymes to Confer Protection against Oxidative Damage in PC12 Cells. J. Agric. Food Chem. 2015, 63, 1521-1531. [CrossRef] [PubMed]

7. Mohan, S.; Gobinath, T.; Salomy, A.; Nisha, M.; Kandasamy, M.; Essa, M.M.; Jayachandran, K.S.; Anusuyadevi, M. Biophysical interaction of resveratrol with sirtuin pathway: Significance in Alzheimer's disease. Front. Neurosci. 2018, 1, 1380-1390.

8. Neves, M.F.; Trombin, V.G.; Lopes, F.F.; Kalaki, R.; Milan, P. World consumption of beverages. In The Orange Juice Business; Wageningen Academic Publishers: Wageningen, The Netherlands, 2011.

9. Tafulo, P.A.R.; Queirós, R.B.; Delerue-Matos, C.M.; Sales, M.G.F. Control and comparison of the antioxidant capacity of beers. Food Res. Int. 2010, 43, 1702-1709. [CrossRef]

10. Buiatti, S. Beer Composition: An Overview. Beer Health Dis. Prev. 2009, 213-225.

11. Bamforth, C.W. Nutritional aspects of beer-A review. Nutr. Res. 2002, 22, 227-237. [CrossRef]

12. de Gaetano, G.; Costanzo, S.; Di Castelnuovo, A.; Badimon, L.; Bejko, D.; Alkerwi, A.; Chiva-Blanch, G.; Estruch, R.; La Vecchia, C.; Panico, S.; et al. Effects of moderate beer consumption on health and disease: A consensus document. Nutr. Metab. Cardiovasc. Dis. 2016, 26, 443-467. [CrossRef] [PubMed]

13. Pai, T.V.; Sawant, S.Y.; Ghatak, A.A.; Chaturvedi, P.A.; Gupte, A.M.; Desai, N.S. Characterization of Indian beers: Chemical composition and antioxidant potential. J. Food Sci. Technol. 2015, 52, 1414-1423. [CrossRef] [PubMed]

14. Khan, M.M.; Raza, S.S.; Javed, H.; Ahmad, A.; Khan, A.; Islam, F.; Safhi, M.M.; Islam, F. Rutin Protects Dopaminergic Neurons from Oxidative Stress in an Animal Model of Parkinson's Disease. Neurotox. Res. 2012, 22, 1-15. [CrossRef] [PubMed]

15. Liu, R.; Guo, X.; Park, Y.; Wang, J.; Huang, X.; Hollenbeck, A.; Blair, A.; Chen, H. Alcohol Consumption, Types of Alcohol, and Parkinson's Disease. PLoS ONE 2013, 8, e66452. [CrossRef]

16. Gonzalez-Muñoz, M.J.; Meseguer, I.; Sanchez-Reus, M.I.; Schultz, A.; Olivero, R.; Benedí,J.; Sánchez-Muniz, F.J. Beer consumption reduces cerebral oxidation caused by aluminum toxicity by normalizing gene expression of tumor necrotic factor alpha and several antioxidant enzymes. Food Chem. Toxicol. 2008, 46, 1111-1118. [CrossRef]

17. Kok, E.H.; Karppinen, T.T.; Luoto, T.; Alafuzoff, I.; Karhunen, P.J. Beer Drinking Associates with Lower Burden of Amyloid Beta Aggregation in the Brain: Helsinki Sudden Death Series. Alcohol. Clin. Exp. Res. 2016, 40, 1473-1478. [CrossRef] [PubMed]

18. Ano, Y.; Dohata, A.; Taniguchi, Y.; Hoshi, A.; Uchida, K.; Takashima, A.; Nakayama, H. Iso- $\alpha$-acids, Bitter Components of Beer, Prevent Inflammation and Cognitive Decline Induced in a Mouse Model of Alzheimer's Disease. J. Biol. Chem. 2017, 292, 3720-3728. [CrossRef] 
19. Stranahan, A.M.; Mattson, M.P. Recruiting Adaptive Cellular Stress Responses for Successful Brain Aging. Nat. Rev. Neurosci. 2012, 13, 209-216. [CrossRef]

20. Pohanka, M. Alzheimer's disease and oxidative stress: A review. Curr. Med. Chem. 2014, 21, 356-364. [CrossRef]

21. Jha, A.B.; Panchal, S.S.; Shah, A. Ellagic acid: Insights into its neuroprotective and cognitive enhancement effects in sporadic Alzheimer's disease. Pharmacol. Biochem. Behav. 2018, 175, 33-46. [CrossRef]

22. Brose, R.D.; Lehrmann, E.; Zhang, Y.; Reeves, R.H.; Smith, K.D.; Mattson, M.P. Hydroxyurea attenuates oxidative, metabolic, and excitotoxic stress in rat hippocampal neurons and improves spatial memory in a mouse model of Alzheimer's disease. Neurobiol. Aging 2018, 72, 121-133. [CrossRef] [PubMed]

23. Li, H.; Xia, N.; Förstermann, U. Cardiovascular effects and molecular targets of resveratrol. Nitric Oxide 2012, 26, 102-110. [CrossRef] [PubMed]

24. Sanchez-Melgar, A.; Albasanz, J.L.; Guixa-Gonzalez, R.; Saleh, N.; Selent, J.; Martin, M. The antioxidant resveratrol acts as a non-selective adenosine receptor agonist. Free Radic. Biol. Med. 2019, 135, 261-273. [CrossRef]

25. Ribeiro, J.A.; Sebastião, A.M.; de Mendonça, A. Adenosine receptors in the nervous system: Pathophysiological implications. Prog. Neurobiol. 2002, 68, 377-392. [CrossRef]

26. Rahman, A. The Role of Adenosine in Alzheimer's Disease. Curr. Neuropharmacol. 2009, 7, $207-216$. [CrossRef]

27. Albasanz, J.L.; Perez, S.; Barrachina, M.; Ferrer, I.; Martín, M. Up-regulation of Adenosine Receptors in the Frontal Cortex in Alzheimer's Disease. Brain Pathol. 2008, 18, 211-219. [CrossRef] [PubMed]

28. Kolahdouzan, M.; Hamadeh, M.J. The neuroprotective effects of caffeine in neurodegenerative diseases. CNS Neurosci. Ther. 2017, 23, 272-290. [CrossRef]

29. Nehlig, A. Effects of coffee/caffeine on brain health and disease: What should I tell my patients? Pract. Neurol. 2016, 16, 89-95. [CrossRef]

30. Borea, P.A.; Gessi, S.; Merighi, S.; Varani, K. Adenosine as a Multi-Signalling Guardian Angel in Human Diseases: When, Where and How Does it Exert its Protective Effects? Trends Pharmacol. Sci. 2016, 37, 419-434. [CrossRef]

31. Wei, C.J.; Li, W.; Chen, J.F. Normal and abnormal functions of adenosine receptors in the central nervous system revealed by genetic knockout studies. Biochim. Biophys. Acta 2011, 1808, 1358-1379. [CrossRef]

32. Martire, A.; Lambertucci, C.; Pepponi, R.; Ferrante, A.; Benati, N.; Buccioni, M.; Dal Ben, D.; Marucci, G.; Klotz, K.N.; Volpini, R.; et al. Neuroprotective potential of adenosine A1 receptor partial agonists in experimental models of cerebral ischemia. J. Neurochem. 2019, 149, 211-230. [CrossRef] [PubMed]

33. Chen, Y.; Yang, S.H.; Hueng, D.Y.; Syu, J.P.; Liao, C.C.; Wu, Y.C. Cordycepin induces apoptosis of C6 glioma cells through the adenosine 2A receptor-p53-caspase-7-PARP pathway. Chem. Biol. Interact. 2014, 216, 17-25. [CrossRef] [PubMed]

34. Castillo, C.A.; Leon, D.; Ruiz, M.A.; Albasanz, J.L.; Martin, M. Modulation of adenosine A1 and A2A receptors in C6 glioma cells during hypoxia: Involvement of endogenous adenosine. J. Neurochem. 2008, 105, 2315-2329. [CrossRef] [PubMed]

35. Bernardi, A.; Bavaresco, L.; Wink, M.R.; Jacques-Silva, M.C.; Delgado-Canedo, A.; Lenz, G.; Battastini, A.M. Indomethacin stimulates activity and expression of ecto-5'-nucleotidase/CD73 in glioma cell lines. Eur. J. Pharmacol. 2007, 569, 8-15. [CrossRef] [PubMed]

36. Appel, E.; Kazimirsky, G.; Ashkenazi, E.; Kim, S.G.; Jacobson, K.A.; Brodie, C. Roles of BCL-2 and caspase 3 in the adenosine A3 receptor-induced apoptosis. J. Mol. Neurosci. 2001, 17, 285-292. [CrossRef]

37. Castillo, C.A.; León, D.A.; Ballesteros-Yáñez, I.; Albasanz, J.L.; Martín, M. Glutamate differently modulates excitatory and inhibitory adenosine receptors in neuronal and glial cells. Neurochem. Int. 2010, 57, $33-42$. [CrossRef]

38. Giunta, S.; Andriolo, V.; Castorina, A. Dual blockade of the A1 and A2A adenosine receptor prevents amyloid beta toxicity in neuroblastoma cells exposed to aluminum chloride. Int. J. Biochem. Cell Biol. 2014, 54, 122-136. [CrossRef]

39. Giust, D.; Da Ros, T.; Martín, M.; Albasanz, J.L. [60]Fullerene derivative modulates adenosine and metabotropic glutamate receptors gene expression: A possible protective effect against hypoxia. J. Nanobiotechnol. 2014, 12, 27. [CrossRef] 
40. Falsini, M.; Catarzi, D.; Varano, F.; Dal Ben, D.; Marucci, G.; Buccioni, M.; Volpini, R.; Di Cesare Mannelli, L.; Ghelardini, C.; Colotta, V. Novel 8-amino-1,2,4-triazolo[4,3-a]pyrazin-3-one derivatives as potent human adenosine A1 and A2A receptor antagonists. Evaluation of their protective effect against beta-amyloid-induced neurotoxicity in SH-SY5Y cells. Bioorg. Chem. 2019, 87, 380-394. [CrossRef]

41. Ferreira, D.G.; Batalha, V.L.; Vicente Miranda, H.; Coelho, J.E.; Gomes, R.; Goncalves, F.Q.; Real, J.I.; Rino, J.; Albino-Teixeira, A.; Cunha, R.A.; et al. Adenosine A2A Receptors Modulate alpha-Synuclein Aggregation and Toxicity. Cereb. Cortex 2017, 27, 718-730. [CrossRef]

42. Razali, N.; Agarwal, R.; Agarwal, P.; Froemming, G.R.A.; Tripathy, M.; Ismail, N.M. IOP lowering effect of topical trans-resveratrol involves adenosine receptors and TGF-beta2 signaling pathways. Eur. J. Pharmacol. 2018, 838, 1-10. [CrossRef] [PubMed]

43. Sanchez-Melgar, A.; Albasanz, J.L.; Palomera-Avalos, V.; Pallas, M.; Martin, M. Resveratrol Modulates and Reverses the Age-Related Effect on Adenosine-Mediated Signalling in SAMP8 Mice. Mol. Neurobiol. 2019, 56, 2881-2895. [CrossRef] [PubMed]

44. Castillo, C.A.; Albasanz, J.L.; Fernández, M.; Martín, M. Endogenous Expression of Adenosine A1, A2 and A3 Receptors in Rat C6 Glioma Cells. Neurochem. Res. 2007, 32, 1056-1070. [CrossRef] [PubMed]

45. Buira, S.P.; Albasanz, J.L.; Dentesano, G.; Moreno, J.; Martín, M.; Ferrer, I.; Barrachina, M. DNA methylation regulates adenosine A2A receptor cell surface expression levels. J. Neurochem. 2010, 112, 1273-1285. [CrossRef] [PubMed]

46. Lowry, O.H.; Rosebrough, N.J.; Farr, A.L.; Randall, R.J. Protein measurement with the Folin phenol reagent. J. Biol. Chem. 1951, 193, 265-275. [PubMed]

47. Huang, W.-J.; Zhang, X.; Chen, W.-W. Association between alcohol and Alzheimer's disease. Exp. Ther. Med. 2016, 12, 1247-1250. [CrossRef] [PubMed]

48. Solfrizzi, V.; D’Introno, A.; Colacicco, A.M.; Capurso, C.; Parigi, A.D.; Baldassarre, G.; Scapicchio, P.; Scafato, E.; Amodio, M.; Capurso, A.; et al. Alcohol consumption, mild cognitive impairment, and progression to dementia. Neurology 2007, 68, 1790-1799. [CrossRef]

49. Solfrizzi, V.; Panza, F.; Frisardi, V.; Seripa, D.; Logroscino, G.; Imbimbo, B.P.; Pilotto, A. Diet and Alzheimer's disease risk factors or prevention: The current evidence. Expert Rev. Neurother. 2011, 11, 677-708. [CrossRef]

50. Bhat, A.H.; Dar, K.B.; Anees, S.; Zargar, M.A.; Masood, A.; Sofi, M.A.; Ganie, S.A. Oxidative stress, mitochondrial dysfunction and neurodegenerative diseases; a mechanistic insight. Biomed. Pharmacother. 2015, 74, 101-110. [CrossRef]

51. Formella, I.; Svahn, A.J.; Radford, R.A.W.; Don, E.K.; Cole, N.J.; Hogan, A.; Lee, A.; Chung, R.S.; Morsch, M. Real-time visualization of oxidative stress-mediated neurodegeneration of individual spinal motor neurons in vivo. Redox Biol. 2018, 19, 226-234. [CrossRef]

52. Perry, G.; Cash, A.D.; Smith, M.A. Alzheimer Disease and Oxidative Stress. J. BioMed. Biotechnol. 2002, 2, 120-123. [CrossRef] [PubMed]

53. Ilomaki, J.; Jokanovic, N.; Tan, E.C.; Lonnroos, E. Alcohol Consumption, Dementia and Cognitive Decline: An Overview of Systematic Reviews. Curr. Clin. Pharmacol. 2015, 10, 204-2012. [CrossRef] [PubMed]

54. Ruitenberg, A.; Swieten, v.J.C.; Witteman, J.C.M.; Mehta, K.M.; Duijn, v.C.M.; Hofman, A.; Breteler, M.M.B. Alcohol consumption and risk of dementia: The Rotterdam Study. Lancet 2002, 359, 281-286. [CrossRef]

55. Heymann, D.; Stern, Y.; Cosentino, S.; Tatarina-Nulman, O.; Dorrejo, J.N.; Gu, Y. The association between alcohol use and the progression of Alzheimer's disease. Curr. Alzheimer Res. 2016, 13, 1356-1362. [CrossRef] [PubMed]

56. Langballe, E.M.; Ask, H.; Holmen, J.; Stordal, E.; Saltvedt, I.; Selbæk, G.; Fikseaunet, A.; Bergh, S.; Nafstad, P.; Tambs, K. Alcohol consumption and risk of dementia up to 27 years later in a large, population-based sample: The HUNT study, Norway. Eur. J. Epidemiol. 2015, 30, 1049-1056. [CrossRef] [PubMed]

57. Luchsinger, J.A.; Tang, M.-X.; Siddiqui, M.; Shea, S.; Mayeux, R. Alcohol intake and risk of dementia. J. Am. Geriatr. Soc. 2004, 52, 540-546. [CrossRef]

58. Neafsey, E.J.; Collins, M.A. Moderate alcohol consumption and cognitive risk. Neuropsychiat. Dis. Treat 2011, 7, 465-484. [CrossRef]

59. Xu, W.; Wang, H.; Wan, Y.; Tan, C.; Li, J.; Tan, L.; Yu, J.-T. Alcohol consumption and dementia risk: A dose-response meta-analysis of prospective studies. Eur. J. Epidemiol. 2017, 32, 31-42. [CrossRef] 
60. Arranz, S.; Chiva-Blanch, G.; Valderas-Martínez, P.; Medina-Remón, A.; Lamuela-Raventós, R.M.; Estruch, R. Wine, Beer, Alcohol and Polyphenols on Cardiovascular Disease and Cancer. Nutrients 2012, 4, 759-781. [CrossRef]

61. Peña, A.; Meseguer, I.; González-Muñoz, M.J. Influence of moderate beer consumption on aluminium toxico-kynetics: Acute study. Nutricion Hospitalaria 2007, 22, 371-376.

62. Collins, M.A.; Neafsey, E.J.; Mukamal, K.J.; Gray, M.O.; Parks, D.A.; Das, D.K.; Korthuis, R.J. Alcohol in Moderation, Cardioprotection and Neuroprotection: Epidemiological Considerations and Mechanistic Studies. Alcohol Clin. Exp. Res. 2009, 33, 206-219. [CrossRef] [PubMed]

63. Fogarasi, A.-L.; Kun, S.; Tankó, G.; Stefanovits-Bányai, É.; Hegyesné-Vecseri, B. A comparative assessment of antioxidant properties, total phenolic content of einkorn, wheat, barley and their malts. Food Chem. 2015, 167, 1-6. [CrossRef]

64. Koren, D.; Orbán, C.; Galló, N.; Kun, S.; Vecseri-Hegyes, B.; Kun-Farkas, G. Folic acid content and antioxidant activity of different types of beers available in Hungarian retail. J. Food Sci. Technol. 2017, 54, 1158-1167. [CrossRef] [PubMed]

65. Spreng, S.; Hofmann, T. Activity-Guided Identification of in Vitro Antioxidants in Beer. J. Agric. Food Chem. 2018, 66, 720-731. [CrossRef] [PubMed]

66. Sivanantham, B.; Krishnan, U.; Rajendiran, V. Amelioration of oxidative stress in differentiated neuronal cells by rutin regulated by a concentration switch. Biomed. Pharmacother. 2018, 108, 15-26. [CrossRef] [PubMed]

67. Rekha, K.R.; Inmozhi Sivakamasundari, R. Geraniol Protects Against the Protein and Oxidative Stress Induced by Rotenone in an In Vitro Model of Parkinson's Disease. Neurochem. Res. 2018. [CrossRef]

68. Beking, K.; Vieira, A. Flavonoid intake and disability-adjusted life years due to Alzheimer's and related dementias: A population-based study involving twenty-three developed countries. Public Health Nutr. 2010, 13, 1403-1409. [CrossRef]

69. Kim, Y.A.; Lim, S.-Y.; Rhee, S.-H.; Park, K.Y.; Kim, C.-H.; Choi, B.T.; Lee, S.J.; Park, Y.-M.; Choi, Y.H. Resveratrol inhibits inducible nitric oxide synthase and cyclooxygenase-2 expression in $\beta$-amyloid-treated C6 glioma cells. Int. J. Mol. Med. 2006, 17, 1069-1075. [CrossRef]

70. Luo, L.; Bai, R.; Zhao, Y.; Li, J.; Wei, Z.; Wang, F.; Sun, B. Protective Effect of Grape Seed Procyanidins against H2 O2 -Induced Oxidative Stress in PC-12 Neuroblastoma Cells: Structure-Activity Relationships. J. Food Sci. 2018. [CrossRef]

71. Ristivojević, P.M.; Morlock, G.E. Effect-directed classification of biological, biochemical and chemical profiles of 50 German beers. Food Chem. 2018, 260, 344-353. [CrossRef]

72. Česlová, L.; Holčapek, M.; Fidler, M.; Drštičková, J.; Lísa, M. Characterization of prenylflavonoids and hop bitter acids in various classes of Czech beers and hop extracts using high-performance liquid chromato...PubMed-NCBI. J. Chromatogr. A 2009, 1216, 7249-7257. [CrossRef] [PubMed]

73. Almeida, C.; Duarte, I.F.; Barros, A.; Rodrigues, J.; Spraul, M.; Gil, A.M. Composition of Beer by 1H NMR Spectroscopy: Effects of Brewing Site and Date of Production. J. Agric. Food Chem. 2006, 54, 700-706. [CrossRef] [PubMed]

74. Cunha, R.A. Neuroprotection by adenosine in the brain: From A1 receptor activation to A2A receptor blockade. Purinergic Signal. 2005, 1, 111-134. [CrossRef] [PubMed]

75. Stone, T.W.; Ceruti, S.; Abbracchio, M.P. Adenosine Receptors and Neurological Disease: Neuroprotection and Neurodegeneration. Handb. Exp. Pharmacol. 2009, 193, 535-587.

76. Albasanz, J.L.; Rodríguez, A.; Ferrer, I.; Martín, M. Up-regulation of adenosine A1 receptors in frontal cortex from Pick's disease cases. Eur. J. Neurosci. 2007, 26, 3501-3508. [CrossRef]

77. Villar-Menéndez, I.; Porta, S.; Buira, S.P.; Pereira-Veiga, T.; Díaz-Sánchez, S.; Albasanz, J.L.; Ferrer, I.; Martín, M.; Barrachina, M. Increased striatal adenosine A2A receptor levels is an early event in Parkinson's disease-related pathology and it is potentially regulated by miR-34b. Neurobiol. Dis. 2014, 69, 206-214. [CrossRef] [PubMed]

78. Woods, L.T.; Ajit, D.; Camden, J.M.; Erb, L.; Weisman, G.A. Purinergic receptors as potential therapeutic targets in Alzheimer's disease. Neuropharmacology 2016, 104, 169-179. [CrossRef]

79. Albasanz, J.L.; León, D.; Ruíz, M.A.; Fernández, M.; Martín, M. Adenosine A1 receptor agonist treatment up-regulates rat brain metabotropic glutamate receptors. Biochim. Biophys. Acta Mol. Cell Res. 2002, 1593, 69-75. [CrossRef] 
80. Reichelt, M.E.; Shanu, A.; Willems, L.; Witting, P.K.; Ellis, N.A.; Blackburn, M.R.; Headrick, J.P. Endogenous adenosine selectively modulates oxidant stress via the A1 receptor in ischemic hearts. Antioxid. Redox Signal. 2009, 11, 2641-2650. [CrossRef]

81. Zhou, X.; Teng, B.; Tilley, S.; Mustafa, S.J. A1 adenosine receptor negatively modulates coronary reactive hyperemia via counteracting A2A-mediated $\mathrm{H} 2 \mathrm{O} 2$ production and KATP opening in isolated mouse hearts. Am. J. Physiol. Heart Circ. Physiol. 2013, 305, H1668-H1679. [CrossRef]

82. Narayan, P.; Mentzer, R.M.; Lasley, R.D. Adenosine A1 receptor activation reduces reactive oxygen species and attenuates stunning in ventricular myocytes. J. Mol. Cell. Cardiol. 2001, 33, 121-129. [CrossRef] [PubMed]

83. Mendes, F.B.; Bergamin, L.S.; Dos Santos Stuepp, C.; Braganhol, E.; Terroso, T.; Pohlmann, A.R.; Guterres, S.S.; Battastini, A.M. Alpha-bisabolol Promotes Glioma Cell Death by Modulating the Adenosinergic System. Anticancer Res. 2017, 37, 1819-1823. [CrossRef] [PubMed]

84. Bobermin, L.D.; Roppa, R.H.A.; Quincozes-Santos, A. Adenosine receptors as a new target for resveratrol-mediated glioprotection. Biochim. Biophys. Acta Mol. Basis Dis. 2019, 1865, 634-647. [CrossRef]

85. Chen, S.-Q.; Wang, Z.-S.; Ma, Y.-X.; Zhang, W.; Lu, J.-L.; Liang, Y.-R.; Zheng, X.-Q.; Chen, S.-Q.; Wang, Z.-S.; Ma, Y.-X.; et al. Neuroprotective Effects and Mechanisms of Tea Bioactive Components in Neurodegenerative Diseases. Molecules 2018, 23, 512. [CrossRef] [PubMed]

(C) 2019 by the authors. Licensee MDPI, Basel, Switzerland. This article is an open access article distributed under the terms and conditions of the Creative Commons Attribution (CC BY) license (http://creativecommons.org/licenses/by/4.0/). 